\title{
Growth Promotion and Disease Suppression Ability of a Streptomyces sp. CB-75 from Banana Rhizosphere Soil
}

\author{
Yufeng Chen ${ }^{1,2 t}$, Dengbo Zhou ${ }^{2 t}$, Dengfeng $\mathrm{Qi}^{2}$, Zhufen $\mathrm{Gao}^{2}$, Jianghui $\mathrm{Xie}^{2 *}$ and \\ Yanping Luo ${ }^{\text {** }}$ \\ ${ }^{1}$ Institute of Tropical Agriculture and Forestry, Hainan University, Haikou, China, ${ }^{2}$ Institute of Tropical Bioscience and \\ Biotechnology, China Academy of Tropical Agricultural Sciences, Haikou, China
}

OPEN ACCESS

Edited by:

Jack Wong,

The Chinese University of Hong Kong

Hong Kong

Reviewed by:

Learn-Han Lee,

Monash University Malaysia, Malaysia

D. Ipek Kurtboke,

University of the Sunshine Coast,

Australia

*Correspondence:

Jianghui Xie

2453880045@qq.com

Yanping LuO

yanpluo@126.com

${ }^{\dagger}$ These authors have contributed equally to this work and co-first authors.

Specialty section:

This article was submitted to Antimicrobials, Resistance and

Chemotherapy,

a section of the journa

Frontiers in Microbiology

Received: 23 August 2017 Accepted: 29 December 2017

Published: 17 January 2018

Citation:

Chen Y, Zhou D, Qi D, Gao Z, Xie J and Luo Y (2018) Growth Promotion and Disease Suppression Ability of a Streptomyces sp. CB-75 from Banana

Rhizosphere Soil.

Front. Microbiol. 8:2704.

doi: 10.3389/fmicb.2017.02704
An actinomycete strain, CB-75, was isolated from the soil of a diseased banana plantation in Hainan, China. Based on phenotypic and molecular characteristics, and 99.93\% sequence similarity with Streptomyces spectabilis NBRC 13424 (AB184393), the strain was identified as Streptomyces sp. This strain exhibited broad-spectrum antifungal activity against 11 plant pathogenic fungi. Type I polyketide synthase (PKS-I) and non-ribosomal peptide synthetase (NRPS) were detected, which were indicative of the antifungal compounds that Streptomyces sp. CB-75 could produce. An ethyl acetate extract from the strain exhibited the lowest minimum inhibitory concentration (MIC) against Colletotrichum musae (ATCC 96167) $(0.78 \mu \mathrm{g} / \mathrm{ml}$ ) and yielded the highest antifungal activity against Colletotrichum gloeosporioides (ATCC 16330) $(50.0 \mu \mathrm{g} / \mathrm{ml})$. Also, spore germination was significantly inhibited by the crude extract. After treatment with the crude extract of Streptomyces sp. CB-75 at the concentration $2 \times \mathrm{MIC}$, the pathogenic fungi showed deformation, shrinkage, collapse, and tortuosity when observed by scanning electron microscopy (SEM). By gas chromatography-mass spectrometry (GC-MS) of the crude extract, 18 chemical constituents were identified; (Z)-13-docosenamide was the major constituent. Pot experiments showed that the incidence of banana seedlings was reduced after using Streptomyces sp. CB-75 treatment. The disease index was 10.23, and the prevention and control effect was 83.12\%. Furthermore, Streptomyces sp. CB-75 had a growth-promoting effect on banana plants. The chlorophyll content showed $88.24 \%$ improvement, the leaf area, root length, root diameter, plant height, and stem showed 88.24, 90.49, 136.17, 61.78, and $50.98 \%$ improvement, respectively, and the shoot fresh weight, root fresh weight, shoot dry weight, and root dry weight showed 82.38, 72.01, 195.33, and 113.33\% improvement, respectively, compared with treatment of fermentation broth without Streptomyces sp. CB-75. Thus, Streptomyces sp. CB-75 is an important microbial resource as a biological control against plant pathogenic fungi and for promoting banana growth.

Keywords: Streptomyces spectabilis, banana Fusarium wilt, antifungal activity, biosynthetic genes, GC-MS, pot experiments 


\section{INTRODUCTION}

Phytopathogenic fungi are most worrying, resulting in significant crop yield losses. In addition, some of the fungi produce toxic compounds (Chaiharn et al., 2009). For instance, Fusarium, Penicillium, and Aspergillus species yield mycotoxins that are harmful to human beings (Almaguer et al., 2012). It is necessary that new and effective methods are sought to prevent phytopathogenic fungi, and to produce crops safe for consumption, as well as to increase crop yield (Law et al., 2017). Due to the increasing incidence of resistance and potential environmental contamination from chemical fungicides, researchers are trying hard to search for novel plant protectants (Wang C. L. et al., 2013). Therefore, it is a good to turn an eye to nature to find antagonistic microorganisms and metabolites (Williams, 2009).

Actinomycetes are one of the most efficient groups of natural bioactive metabolites, and they have been used as antibiotics, antitumor agents, antioxidants, anti-inflammatory agents, antiinfection agents, enzyme inhibitors, pesticides, plant-growthpromoting substances, and so on (Qin et al., 2011; Wang X. J. et al., 2013; Ashokvardhan et al., 2014; Kumar V. et al., 2014; Shivlata and Satyanarayana, 2015; Tan et al., 2016). It has been reported that actinomycetes have been used to protect plants against a wide range of phytopathogenic fungi, and produce cellwall degrading enzymes, antifungal antibiotics, and plant growth promoters (Yuan and Crawford, 1995; El-Tarabily et al., 2000; Doumbou et al., 2002; Bressan, 2003; Cao et al., 2005; El-Tarabily and Sivasithamparam, 2006; Prapagdee et al., 2008; Jorjandi et al., 2009; Eccleston et al., 2010; Mingma et al., 2014).

Among bioactive compound producers, the genus Streptomyces is dominant, and produces compounds such as ivermectin, tetracycline, streptomycin, nystatin, etc. (Ser et al., 2016). Streptomyces species are Gram-positive, filamentous, and sporulating actinobacteria, with a high $\mathrm{G}+\mathrm{C}$ content in their genomes (Lyu et al., 2017). They exhibit an immense biocontrol activity against a range of phytopathogens (Wang X. N. et al., 2013). Streptomyces have been long considered simply as freeliving soil inhabitants, they can act as plant-growth promoters or as biocontrol agents against soil-borne pathogens (Seipke et al., 2011). Streptomyces are regarded as important biological resources, due to their biologically active secondary metabolites; these antimicrobial compounds play roles in protecting plants against pathogens (Ueno et al., 2016). Getha and Vikineswary (2002) found that Streptomyces violaceusniger had a strong inhibitory effect on banana Fusarium wilt, and a preventative effect $(48-52 \%)$ on potted plants. Pseudomonas aeruginosa, isolated from the banana rhizosphere, has been used as a biological fertilizer to increase banana plant height and reduce vascular discoloration caused by Fusarium wilt (Ayyadurai et al., 2006). Therefore, the isolation of antagonistic actinomycetes is considered to be an important step in the development of

Abbreviations: DMSO, Dimethyl sulfoxide; EtOAc, ethyl acetate; GC-MS, gas chromatography-mass spectrometry; MIC, minimum inhibitory concentration; NRPS, non-ribosomal peptide synthetase; PKS, polyketide synthase; SEM, scanning electron microscopy. agriculture, ecosystem safety regulations, and the prevention and control of plant diseases (Lu et al., 2016).

In this study, we isolated and screened Streptomyces sp. CB-75 from the soil of a diseased banana plantation. According to $16 \mathrm{~S}$ rRNA sequence analysis, combined with morphological, culture, physiological, and biochemical characteristics, the taxonomic status of the strain was determined. A preliminary study was performed on the CB-75 strain's antifungal activities against a wide range of fungal pathogens and its effect on potted plants. Also, the antifungal activities of extractions of Streptomyces sp. CB-75 were evaluated. Gas chromatography-mass spectrometry (GC-MS) was used to perform chemical analysis of the crude extract of Streptomyces sp. CB-75 in order to reveal the chemical constituents present. The aim of this study was to uncover microbial resources, and utilize them in plant protection and microbial fertilizers.

\section{MATERIALS AND METHODS}

\section{Sampling Site and Sample Collection}

Rhizosphere soils, an approximately $10-20 \mathrm{~cm}$ layer, were collected from banana plantations in May 2016 in Nanbao $\left(109^{\circ} 51^{\prime} 17^{\prime \prime} \mathrm{E}, 19^{\circ} 47^{\prime} 1^{\prime \prime} \mathrm{N}\right)$, Meitai $\left(109^{\circ} 35^{\prime} 58^{\prime \prime} \mathrm{E}, 19^{\circ} 40^{\prime} 51^{\prime \prime} \mathrm{N}\right)$, and Huangtong $\left(109^{\circ} 50^{\prime} 58^{\prime \prime} \mathrm{E}, 19^{\circ} 49^{\prime} 58^{\prime \prime} \mathrm{N}\right)$ of the Hainan Province, China, transferred into sterile plastic bags using an aseptic metal trowel, and stored at $-20^{\circ} \mathrm{C}$.

\section{Test Phytopathogenic Fungi}

The following test phytopathogenic fungi were used in the experiments: Fusarium oxysporum f. sp. cubense Race 1 (ATCC 76244); F. oxysporum f. sp. cubense Race 4 (ATCC 76255); Colletotrichum gloeosporioides (Penzig) (ATCC 58222); Colletotrichum fragariae Brooks (ATCC 58718); Colletotrichum acutatum Simmonds (ATCC 56815); Botrytis cinerea Persoon (ATCC 11542); Colletotrichum musae (ATCC 96167); Curvulatia fallax (ATCC 38579); C. gloeosporioides (ATCC MYA-456; Alternaria tenuissima (ATCC 26513); C. gloeosporioides (ATCC 16330). These fungi were provided by the Institute of Environment and Plant Protection, China Academy of Tropical Agricultural Sciences, Haikou, China.

\section{Isolation of Actinomycetes}

Actinomycetes were isolated by serial dilution method on Gause's no. 1 medium (Williams et al., 1983; Wang L. Y. et al., 2015). Rifampicin (50 mg/l) and nystatin (50 mg/l) were added to inhibit bacterial and fungal growth. To prepare the soil suspension, $10 \mathrm{~g}$ of the dried soil sample was transferred into a $250-\mathrm{ml}$ bottle, and $90 \mathrm{ml}$ sterile distilled water was added to the bottle, with shaking for $30 \mathrm{~min}$. Soil suspensions from $10^{-3}$ to $10^{-5}$-fold dilutions were aseptically plated onto Gause's no. 1 synthetic medium and incubated at $28^{\circ} \mathrm{C}$ for 7-15 days. Colonies with different morphological characteristics was transferred and purified on yeast extract-malt extract (ISP 2) agar (Shirling and Gottlieb, 1966) at $4^{\circ} \mathrm{C}$, and kept for long term preservation in $20 \%(\mathrm{v} / \mathrm{v})$ glycerol at $-80^{\circ} \mathrm{C}$ (Williams et al., 1983). 


\section{Screening of Actinomycetes}

Antagonistic activities of purified strains were determined by the conventional spot inoculation method (Sadeghian et al., 2016; Sharma et al., 2016), and their extracts with ethyl acetate (EtOAc) were tested using the agar diffusion method, according to Patel et al. (2011) with slight modifications. Actinomycete cakes $(\Phi=5 \mathrm{~mm})$ were inoculated onto one side of potato dextrose agar (PDA) plates (Wang L. Y. et al., 2015), about $2.5 \mathrm{~cm}$ from the center of the plate. A phytopathogenic fungal disc $(\Phi=$ $5 \mathrm{~mm}$ ) was placed in the center of the plate. A fungal disc alone in the center of a plate served as a control. After incubation at $28^{\circ} \mathrm{C}$ for $5-7$ days, the antagonistic belt (inhibition zone) was recorded by measuring the distance between the edge of the fungal mycelium and the actinomycete discs. The percentage inhibition of the radial growth (PIRG) was calculated using the following formula:

$$
\mathrm{PIRG}=[(R 1-R 2) / R 1] \times 100
$$

where $R 1$ was the radius of fungal mycelial growth in the control, and $R 2$ was the radius of fungal mycelial growth that occurred toward the actinomycetes. All strains were tested in three independent experiments (Albuquerque et al., 2006).

\section{Identification and Characterization of the Actinomycete Strain Culture Characteristics}

The culture characteristics of strain CB-75 were examined according to the method of Shirling and Gottlieb (1966). The strain was grown in different culture media (ISP2, ISP3, ISP4, ISP5, ISP6, ISP7, PDA, and Gause's no. 1) (Shirling and Gottlieb, 1966) at $28^{\circ} \mathrm{C}$ for $7-10$ days. Colony colors were distinguished with the ISCC-NBS color charts (Kelly, 1958), and the colony characteristics, including growth, aerial mycelium, spores, and hypha characteristics, were observed. Morphological characteristics were observed under scanning electron microscopy (SEM) (SIGMA Field Emission Scanning Electron Microscope). Growth at various temperatures $\left(4-45^{\circ} \mathrm{C}\right)$ was determined on ISP 2 at $28^{\circ} \mathrm{C}$ for $14-21$ days. The $\mathrm{pH}(3-11)$ and $\mathrm{NaCl}(0-15 \%)$ tolerance for growth were determined on ISP2 at $28^{\circ} \mathrm{C}$ for $14-21$ days. The utilization of carbohydrates as sole carbon sources was tested according to published methods (Gordon et al., 1974). Decomposition of casein, tyrosinase production, H2S production, gelatin liquefaction, nitrate reduction, and starch hydrolysis were assessed according to the reference by Williams et al. (1983). Major diagnostic cell wall sugars of Streptomyces sp. CB-75 were obtained as described by Whiton et al. (1985).

\section{Molecular Identification DNA Extraction and PCR Amplification}

The preparation of genomic DNA of the strain was implemented in accordance with the methods described by Pitcher et al. (1989). The 16S rRNA gene was amplified by PCR with Taq DNA polymerase and the conserved primers $27 \mathrm{~F}\left(5^{\prime}\right.$ AGAGTTTGATCMTGGCTCAG-3') and 1492R (5'-TACGGY TACCTTGTTACGACT-3') (Gupta et al., 2014). PCRs were performed in the TProfessional Trio PCR System (Biometra Germany). The PCR system and conditions were as described by Himaman et al. (2016). The PCR amplification products were visualized by $1.0 \%(\mathrm{w} / \mathrm{v})$ agarose gel electrophoresis. The amplified PCR products were sequenced by a Sanger-based, automated sequencer (Applied Biosystems).

\section{Phylogenetic Analysis}

The almost-complete 16S rRNA gene sequence was compared with those deposited in public databases and the EzBiocloud server (https://www.ezbiocloud.net/identify; Chun et al., 2007; Kim et al., 2012), which was also used to calculate pairwise sequence similarities. The $16 \mathrm{~S}$ rRNA gene sequence of representative related taxa were obtained from the GenBank databases using CLUSTAL_X software (Thompson et al., 1997). The alignment was manually verified and adjusted prior to the reconstruction of a phylogenetic tree. The phylogenetic tree was reconstructed with the neighbor-joining tree algorithm (Saitou and Nei, 1987) and maximum parsimony method (Fitch, 1971) using MEGA version 7.0 (Tamura et al., 2007). The evolutionary distances of the clades in the neighbor-joining tree were estimated by bootstrap analysis (Felsenstein, 1985).

\section{Antifungal Activity Assay EtOAc Extraction}

Streptomyces sp. CB-75 was inoculated in 1,000 ml of sterilized soybean liquid culture medium (SLM) (Hong et al., 2009), and incubated with shaking $(150 \mathrm{rpm})$ at $28^{\circ} \mathrm{C}$ for 7 days. Then, the culture filtrate was extracted with EtOAc at a ratio of 1:1 (v/v). The mixture was filtered through Whatman no. 1 qualitative filter paper and the organic phase (EtOAc) was separated from the filtered liquid media using a decantation funnel. The extraction was evaporated in a rotary vacuum evaporator. The crude extract of Streptomyces sp. CB-75 was prepared by dissolving in $10 \%$ dimethyl sulfoxide (DMSO) at a concentration of 20.0 $\mathrm{mg} / \mathrm{ml}$, and sterilized by filtration through a $0.22 \mu \mathrm{m}$ sterile filter (Millipore, Bedford, MA, USA). The extract were stored at $-4^{\circ} \mathrm{C}$.

\section{Antifungal Activity by Disc Diffusion Assay}

To assess the antifungal activity of the crude extract of Streptomyces sp. CB-75 against 11 indicator plant pathogens, bioassays were carried out using the disc diffusion method (Ashokvardhan and Satyaprasad, 2016; Sharma et al., 2016). Sterilized filter paper discs $(\Phi=6 \mathrm{~mm})$ were impregnated with the crude extract and placed on PDA plates about $3 \mathrm{~cm}$ from the center of the plate. A fungal disc $(\Phi=5 \mathrm{~mm})$ was placed in the center of the plate. A fungal mycelia disc alone in the center of the plate served as a control. The diameters of the inhibition zones were measured after incubation for 7 days at $28^{\circ} \mathrm{C}$. The inhibition zone was equal to R1-R2 (Himaman et al., 2016), where R1 was the radius of fungal mycelial growth in the control and R2 was the radius of fungal mycelial growth that occurred toward Streptomyces sp. CB-75. Three replicates were performed for each treatment, and each assay was repeated three times. 


\section{Antifungal Activity on Mycelia Radial Growth}

The antifungal activity of the crude extract of Streptomyces sp. CB-75 on mycelial growth was assessed by the poisoned food technique (Sharma et al., 2016). The crude extract, dissolved in $10 \%$ DMSO $(20.0 \mathrm{mg} / \mathrm{ml})$, was added to PDA medium at $45-$ $50^{\circ} \mathrm{C}$ to get $100 \mu \mathrm{g} / \mathrm{ml}$. PDA containing the crude extract $(20 \mathrm{ml})$ was poured into sterilized Petri dishes ( $90 \mathrm{~mm}$ in diameter). An equal amount of $10 \%$ DMSO was used as a control. A fungal disc ( $5 \mathrm{~mm}$ in diameter) was inoculated aseptically into the center of each Petri dish. The plates were sealed with polyethylene film, and incubated at a temperature of $28 \pm 2{ }^{\circ} \mathrm{C}$ until the control mycelium reached the edge of the plates. The mean of the perpendicular diameters of each colony was measured. Each assay was repeated three times. The percentage inhibition of the mycelial radial growth was calculated using the following formula:

$$
\text { Percentage Mycelial Inhibition }=\frac{\mathrm{C}-\mathrm{T}}{\mathrm{C}} \times 100
$$

where $\mathrm{C}$ is the mean colony diameter for the control, and $\mathrm{T}$ is the mean colony diameter for the treatment (Nimaichand et al., 2015).

\section{PCR Amplification and Sequencing of Biosynthetic Genes of Streptomyces sp. CB-75 [Genes Encoding Type I Polyketide Synthases (PKS-I) and Non-ribosomal Peptide Synthetases (NRPSs)]}

Two sets of degenerate PCR primers (K1F $5^{\prime}$-TSAAGTCSAA CATCGGBCA-3' and M6R 5'-CGCAGGTTSCSGTACCAGTA$3^{\prime}$ ) targeting PKS-I sequences were used for amplification of ketosynthase and methyl-malonyl transferase domain sequences (Gonzalez et al., 2005). A3F (5'-GCSTACSYSATSTACACST CSGG-3') and A7R (5'-SASGTCVCCSGTSCGGTAS-3') were used for amplification of NRPS adenylation domain sequences (Sharma et al., 2016). PKS-I and NRPS PCR amplifications were performed with a TProfessional Trio PCR System (Biometra, Germany), in a total volume of $25 \mu \mathrm{l}$ consisting of template DNA (50 ng), $2 \times$ PCR Master Mix (12.5 $\mu \mathrm{l}), \mathrm{DDH}_{2} \mathrm{O}(10.5 \mu \mathrm{l})$, $\mathrm{K} 1 \mathrm{~F} / \mathrm{A} 3 \mathrm{~F}(0.5 \mu \mathrm{l})$, and M6R/A7R $(0.5 \mu \mathrm{l})$. The conditions for thermal cycling were as follows: denaturation of the DNA at $95^{\circ} \mathrm{C}$ for $5 \mathrm{~min}$; and 35 cycles at $94^{\circ} \mathrm{C}$ for $30 \mathrm{~s}$, primer annealing $2 \mathrm{~min}$ at $55^{\circ} \mathrm{C}$ for $\mathrm{K} 1 \mathrm{~F} / \mathrm{M} 6 \mathrm{R}$ and $59^{\circ} \mathrm{C}$ for $\mathrm{A} 3 \mathrm{~F} / \mathrm{A} 7 \mathrm{R}$, and DNA elongation at $72^{\circ} \mathrm{C}$ for $4 \mathrm{~min}$. At the end of the PCR, the reaction mixture was held at $72^{\circ} \mathrm{C}$ for $10 \mathrm{~min}$ (Himaman et al., 2016). PCR amplification products were analyzed by electrophoresis in $1 \%(\mathrm{w} / \mathrm{v})$ agarose gel stained with goldview I. The resultant sequences were compared with other known sequences in GenBank by available BLAST methods (http://www. ncbi.nlm.nih.gov/BLAST/).

\section{Determination of the Minimum Inhibitory Concentration (MIC) of Streptomyces sp. CB-75}

A 96-well microtiter assay (Wedge et al., 2003; Wang X. N. et al., 2013) was used to determine the MICs of the crude extract from Streptomyces sp. CB-75 against the test fungal pathogens in comparison with known fungicides. Different concentrations of the crude extract were prepared using two-fold serial dilutions for MIC tests, the final concentrations were 50.0, 25.0, 12.5, 6.25, $3.125,1.563$, and $0.781 \mu \mathrm{g} / \mathrm{ml}$. The lowest concentration of the crude extract that inhibited growth was recorded as the MIC. Each well received $80 \mu \mathrm{l}$ of Roswell Park Memorial Institute (RPMI) mycological media, $100 \mu \mathrm{l}$ of test fungi conidia at 1.0 $\times 10^{5} \mathrm{CFU} / \mathrm{ml}$, and $20 \mu \mathrm{l}$ of antifungal solution from the parent plate. Each test extract was evaluated in duplicate against a noninoculated well (reagent blank) containing test extract and RPMI at each concentration. The 96-well plates (Nunc MicroWell, untreated; Roskilde, Denmark) were covered with a plastic lid and incubated at $24 \pm 1{ }^{\circ} \mathrm{C}$ for a $12 \mathrm{~h}$ photoperiod under $60 \pm 5 \mu \mathrm{mol}$ light. The absorbance was measured at $620 \mathrm{~nm}$ using a microplate photometer (Packard Spectra Count, Packard Instrument Co., Downers Grove, IL, USA). A negative control was prepared using 10\% DMSO, and standard antibiotics such as cycloheximide and nystatin were used as positive controls.

\section{Spore Germination Assay}

The percentage spore germination was calculated using the method of Tzortzakis and Economakis (2007), with slight modifications. Each fungal strain was challenged in a doseresponse format using the crude extract of Streptomyces sp. CB75 , where the final treatment concentrations were $1 \times$ MIC, $2 \times$ MIC, $4 \times$ MIC, and $8 \times$ MIC. Each extract solution was mixed with the fungal spore suspension $\left(10^{5} \mathrm{CFU}\right)$ at a ratio of $1: 1$ $(\mathrm{v} / \mathrm{v})$. The mixture $(0.1 \mathrm{ml})$ was placed on a sterile glass slide. Slides containing the spores were incubated in a moist chamber at $28^{\circ} \mathrm{C}$ for $20 \mathrm{~h}$. A mixture of sterile water and spores was used as a control. Each treatment was repeated three times. Spore germination was observed by electron microscopy (mag $=200$ $\times$ lens). For each treatment, one hundred spores were examined, and the extent of spore germination assessed by looking for germ tube emergence. The number of germinated spores was scored using a hemocytometer, and the percentage of spore germination (PSG) was calculated as follows:

$$
P S G=\frac{\mathrm{A}-\mathrm{B}}{\mathrm{A}} \times 100,
$$

where A was the spore germination rate of the control group, and $\mathrm{B}$ was the spore germination rate of treatment group (Sharma et al., 2017).

\section{SEM}

After treatment with the crude extract of Streptomyces sp. CB75, the cells of F. oxysporum f. sp. cubense Race 4 were observed by SEM according to a previously published method (Supaphon et al., 2013), with slight modifications. The inoculum was prepared by growing the test pathogen for $5 \sim 7$ days. Conidial suspensions were prepared according to published procedures (Wedge and Kuhajek, 1998). Conidial concentrations were determined photometrically (Espinel-Ingroff and Kerkering, 1991; Wedge and Kuhajek, 1998) from a standard curve and suspensions were then adjusted with sterile distilled water to a concentration of $1.0 \times 105$ conidia/ml. Conidia were then treated with the crude extract of CB-75 at the $2 \times$ MIC value for $24 \mathrm{~h}$. The cells were fixed with $2.5 \%(\mathrm{v} / \mathrm{v})$ glutaraldehyde $(\mathrm{C} 3 \mathrm{H} 8 \mathrm{O} 2)$ in phosphate-buffered saline (PBS) for $2 \mathrm{~h}$, and washed with 
PBS ( $\mathrm{pH} 7.4$ ) and water. The cells were dehydrated with series of increasing concentrations of alcohol $(30,50,70,80,90$, and $100 \%$ ) for $20 \mathrm{~min}$. Finally, the ethanol was displaced with isoamyl acetate. The cells were dried for $30 \mathrm{~min}$ and mounted onto a steel stub with double-sided carbon tape. Samples were coated with a film of gold-palladium alloy under vacuum and observed with a scanning electron microscope (Zeiss Sigma VP, Germany).

\section{GC-MS Analysis}

GC-MS analysis was performed to identify the chemical compounds in the crude extract of Streptomyces sp. CB75 , in accordance with a previously described method, with slight modifications (Sun et al., 2015; Supriady et al., 2015). GC-MS analysis was performed on a Shimadzu GC 2010 plus with triple quadrupole mass spectrometer (TP-8030), and fitted with a DB-5ms (5\% phenyl methyl siloxane) capillary column of dimensions $30 \mathrm{~m} \times 0.25 \mathrm{~mm}$ $\times 0.25 \mu \mathrm{m}$, and with helium as a carrier gas at $1 \mathrm{ml} / \mathrm{min}$.
$700 \mathrm{~g}$ was packaged into each plastic pot. Banana seedlings were washed with sterile water, and the second piece of the taproot cut. The plants were aseptically planted into the plastic pots with $700 \mathrm{~g}$ potting soil. The fungal spore suspension of F. oxysporum Race 4 was inoculated into the potting soil, and diluted at the concentration of $10^{5} \mathrm{CFU} / \mathrm{g}$ soil. The banana seedlings were cultivated in a greenhouse. Each experiment was repeated three times.

The grading standards of F. oxysporum f. sp. cubense Race 4, the disease index, and the effect of prevention and control were shown as follows (Himaman et al., 2016):

grade 0 , healthy plant;

grade 1, the leaves of the lower part of the plant were withered; grade $3,20-40 \%$ of the leaves were withered;

grade $4,40-60 \%$ of the leaves were withered; grade $5,60-80 \%$ of the leaves were withered; grade 6 , the entire plant was withered and dead.

$$
\begin{aligned}
\text { Disease Index } & =\frac{\sum(\text { Number of diseased plants of each grade } \times \text { value of relative rade })}{\text { Total number inspected } \times 6} \times 100 \\
\text { Controlling effect }(\%) & =\frac{\text { Sterile water controlled disease index }- \text { treated disease index }}{\text { Sterile water controlled disease index }} \times 100
\end{aligned}
$$

The column temperature was programmed initially at $60^{\circ} \mathrm{C}$, held for $1.0 \mathrm{~min}$, and then increased to $100^{\circ} \mathrm{C}$ at $5.0^{\circ} \mathrm{C} / \mathrm{min}$, held for $5.0 \mathrm{~min}$, and then again raised at $10.0^{\circ} \mathrm{C} / \mathrm{min}$ to $250^{\circ} \mathrm{C}$, held for $35.0 \mathrm{~min}$, and finally raised to $280^{\circ} \mathrm{C}$ at $10.0^{\circ} \mathrm{C} / \mathrm{min}$, and held for $25.0 \mathrm{~min}$. The mass spectrometer was operated in electron ionization (EI) mode at $70 \mathrm{eV}$, with an interface temperature of $280^{\circ} \mathrm{C}$, an ion source temperature of $240^{\circ} \mathrm{C}$, a mass spectrometer acquisition delay time of $3.5 \mathrm{~min}$, and a continuous scan from 50 to $650 \mathrm{amu}$. Peaks were identified by comparison with the mass spectra data from the National Institute of Standards and Technology (NIST) spectral library.

\section{Pot Culture Experiments}

Pot culture experiments were carried out in May-July 2017 at the Institute of Tropical Bioscience and Biotechnology, China Academy of Tropical Agricultural Sciences. The conditions of the greenhouse were $28^{\circ} \mathrm{C}, 70 \%$ humidity, and with natural light. The fermentation broth of Streptomyces sp. was inoculated in sterilized soybean liquid culture medium (SLM), and incubated with shaking $(150 \mathrm{rpm})$ at $28^{\circ} \mathrm{C}$ for 7 days. The fermentation broth was filtered through two layers of sterile prewetted Mira cloth. The filtrate was diluted 50-fold, and $100 \mathrm{ml}$ liquid put into each plastic pot. Five treatment groups were established: CK1 (non-inoculated F. oxysporum Race 4 and application of sterile water); CK2 (inoculated F. oxysporum Race 4 and application of sterile water); CK3 (inoculated F. oxysporum Race 4 and sodium $p$-(dimethylamino) benzenediazo sulfonate); A (inoculated F. oxysporum Race 4 and application of fermentation broth without Streptomyces sp. CB75); AB (inoculated F. oxysporum Race 4 and fermentation broth of Streptomyces sp. CB-75).

Soil was collected from Lingao county, passed through a twenty-mesh sieve, and sterilized at $160^{\circ} \mathrm{C}$ for $2 \mathrm{~h}$, and then

\section{Physiological Indexes of Banana}

The physiological indexes of banana seedlings transplanted at $0,15,30,45$, and 60 days were determined, including chlorophyll content, leaf area, root length, root diameter, plant height, stem, shoot biomass, and root biomass on the 60th day.

\section{Statistical Analysis}

Analysis of variance and multiple comparisons were performed using SAS 6.12 software. All experiments were performed in biological triplicate and repeated three times. The data were expressed as the mean \pm standard deviation of the mean of the three replicates by variance analysis of single factor analysis. Duncan's multiple range test was performed at a significance level of $P<0.05$.

\section{RESULTS}

\section{Isolation of Actinomycetes from the Rhizosphere Soil}

One hundred and thirty morphologically different actinomycetes strains were isolated from the soil of a diseased banana plantation in Hainan, China. Soil niches have been reported to be rich in many significant actinomycetes (Savic et al., 2007; Bizuye et al., 2013; Tan et al., 2015). All isolates were screened for their antifungal activity using a conventional spot inoculation method and the agar diffusion method. Out of all of them, 14 per cent of the isolates exhibited antifungal activity during the preliminary experiment, especially strain CB-75, which exhibited broadspectrum antifungal activity against the tested phytopathogenic fungi. So, Streptomyces sp. CB-75 was selected and identified. 


\section{Characterization of Streptomyces sp. CB-75 \\ Culture Characteristics}

Streptomyces sp. CB-75 was cultured on different media, and its aerial mycelium, substrate mycelium, and soluble pigments were assessed (Table 1). Streptomyces sp. CB-75 grew very well on 8 types of culture media, and did not produce soluble pigments. The aerial mycelia were straight and long under SEM analysis (Figure 1A). It formed spiral chains of rugose ornamented spores (Figure 1B).

\section{Physiological and Biochemical Characteristics}

The physiological and biochemical characteristics of Streptomyces sp. CB-75 have been tabulated into Table 2. Streptomyces sp. CB-75 could reduce nitrate, decompose sulfurcontaining amino acids to $\mathrm{H}_{2} \mathrm{~S}$, and was able to hydrolyze starch and produce melanin. However, Streptomyces sp. CB75 was unable to liquefy gelatin, nor peptonize and solidify milk, and could not produce tyrosinase. It could fully utilize $\alpha$-lactose, D-cellobiose, D-fructose, D-galactose, D-glucose, D-mannose, D-sorbitol, D-trehalose, LL-arabinose, melitose, melibiose, xylan, D-mannitol, melezitose, ribose, saligenin, and soluble starch as carbon sources. Furthermore, the stain could fully utilize L-arginine, L-phenylalanine, glycine, methionine, L-hydroxyproline, L(+)-cysteine, L-homocysteine, valine, histidine, ammonium nitrate, and ammonium chloride as nitrogen sources. It grew at $18 \sim 45^{\circ} \mathrm{C}, \mathrm{pH} 6 \sim 9$, and its optimal growth temperature was $28^{\circ} \mathrm{C}$ and $\mathrm{pH} 7.2$. It grew well in media with less than $5 \% \mathrm{NaCl}$. Its cell wall contained both LL-diaminopimelic acids (DAP) and glycine based on cellulose thin layer chromatography (TLC) analysis, the cell wall of Streptomyces sp. CB-75 belonged to type I, and its whole cell sugar belonged to type C.

\section{Identification and Phylogenetic Analysis of Isolates}

A partial 16S rRNA gene sequence (1,490 nucleotides) of strain CB-75 was determined and submitted to the GenBank database under the accession number KC737552. The strain exhibited the highest similarity with Streptomyces spectabilis NBRC 13424 (AB184393; 99.93\%), using EzBiocloud and GenBank sequence

TABLE 1 | Culture characteristics of Streptomyces sp. CB-75.

\begin{tabular}{llllc}
\hline Medium & $\begin{array}{l}\text { Aerial } \\
\text { mycelium }\end{array}$ & $\begin{array}{l}\text { Vegetative } \\
\text { mycelium }\end{array}$ & $\begin{array}{l}\text { Soluble } \\
\text { pigment }\end{array}$ & $\begin{array}{c}\text { Growth } \\
\text { Growth }\end{array}$ \\
\hline ISP 2 & Light brown & Red-orange & None & +++ \\
ISP 3 & Yellow-pink & Red-orange & None & ++ \\
ISP 4 & White & Dark pink & None & +++ \\
ISP 5 & Orange-pink & Orange-pink & None & + \\
ISP 6 & Pink & Dark pink & None & +++ \\
ISP 7 & Orange & Orange & None & ++ \\
PDA & Pink & Pink & None & ++ \\
Gause's no. 1 agar & Orange-yellow & Red & None & +++ \\
\hline
\end{tabular}

+++ , Good growth; ++, Moderate growth; +, Poor growth. similarity searches and homology analysis. A phylogenetic tree was reconstructed with the neighbor-joining and maximumparsimony methods, using the software package MEGA version 7.0 (Figure 2). Phylogenetic analysis demonstrated that strain CB-75 was closely related to Streptomyces spectabilis NBRC 13424 (AB184393; 99.93\%), as they formed a distinct clade at a high bootstrap value of $100 \%$ (Figure 2). The phenotypic (morphological, physiological, and biochemical characteristics) and genomic data were indicative that strain CB-75 was representative of members of the genus Streptomyces. The strain was referred to as Streptomyces sp. CB-75.

\section{Antifungal Activity Assay of Streptomyces sp. CB-75}

The crude extract from Streptomyces sp. CB-75 showed a wide antifungal spectrum (Table 3). It exhibited excellent inhibitory activity against 11 pathogenic fungi. The best inhibitory activity (the inhibition zones $\pm \mathrm{SD} \mathrm{mm}$ ) was found against C. musae (ATCC 96167) (inhibition zone diameter of $14.93 \pm 0.35$ ) and C. acutatum (ATCC 56815) (14.43 \pm 0.40 ), followed by F. oxysporum Race 4 (ATCC 76255) (13.77 \pm 0.31 ), C. fallax (ATCC 38579) (13.67 \pm 0.31$),$ C. gloeosporioides (ATCC 58222) $(13.50 \pm 0.50)$, B. cinerea (ATCC 11542) (13.23 \pm 0.25$)$, and C. gloeosporioides (ATCC MYA-456) (13.23 \pm 0.38$)$. There was no significant difference with the inhibitory zones $(P<0.05)$. The minimal inhibition zone was $11.40 \pm 0.36 \mathrm{~mm}$ against F. oxysporum Race 1 (ATCC 76244).

Streptomyces sp. CB-75 inhibited mycelial growth of 11 types of pathogenic fungi. The percentage inhibition of the mycelial radial growth values varied greatly among the target species, ranging from 73.11 to $80.96 \%$. The maximum percentage of mycelial growth inhibition was against C. musae (ATCC 96167) $(80.96 \pm 0.78 \%)$ and C. acutatum (ATCC 56815) (79.85 $\pm 0.90 \%)$. The minimum was against $A$. tenuissima (ATCC 26513) $(73.85 \pm$ $0.84 \%$ ) and F. oxysporum Race 1 (ATCC 76244) (73.11 $\pm 0.80 \%)$. Thus, Streptomyces sp. CB-75 showed a wide range of antifungal activity.

\section{Identification of Biosynthetic Genes (Encoding PKS-I and NRPS)}

It is well known that PKSs and NRPSs are biosynthetic enzymes, which induce the formation of active metabolites in actinomycetes (Hodges et al., 2012). It has been helpful to evaluate the biosynthetic potential of actinobacteria through identification of biosynthetic genes (Nimaichand et al., 2015). For PCR amplification of PKS-I-encoding genes, K1F/M6R primers were used corresponding to PKS-I ketosynthase and methylmalonyl-CoA transferase modules, the strain CB-75 had a band size of approximately 1,200-1,400 bp. Sequencing of the gene fragment encoding PKS-I yielded a sequence of $1234 \mathrm{bp}$ (National Center for Biotechnology Information [NCBI] accession no. MF476983). Strain CB-75 showed the highest sequence similarity (84\%) for the PKS-I-encoding gene with a PKS-encoding gene from Streptomyces alboflavus strain MDJK44 (NCBI accession no. CP021748). The NRPS amplicon was found to be 600-700 bp in size, following amplification with A3F/A7R specific primers for NRPS adenylation domain sequences. Sequencing of the NRPS-encoding gene fragment yielded a sequence of $651 \mathrm{bp}$ in 


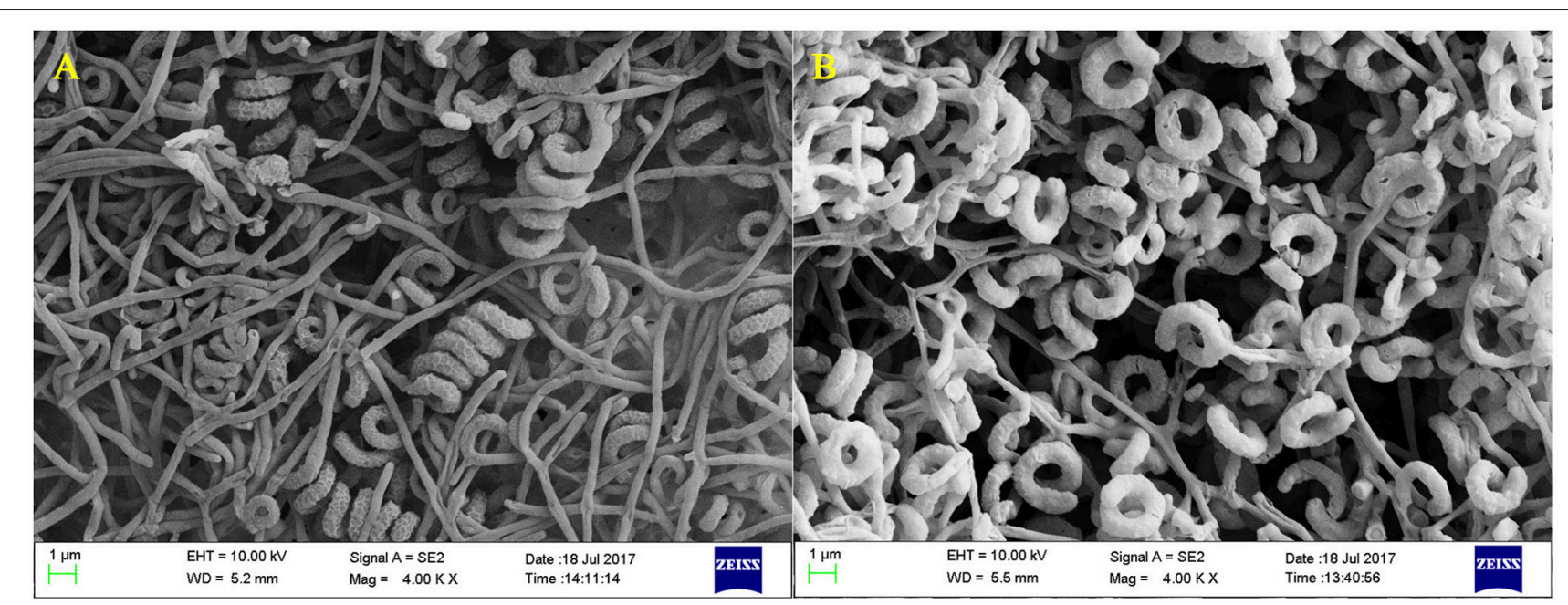

FIGURE 1 | Scanning electron microscope images of Streptomyces sp. CB-75. Morphological characters of aerial mycelia (A) and spores (B) of Streptomyces sp. CB-75 viewed using SEM.

length (NCBI accession no. MF476984). The NRPS sequence of CB-75 showed the highest similarity (96\%) to an NRPS-encoding gene from Streptomyces albus strain NK660 (NCBI accession no. CP007574).

\section{MIC of Streptomyces sp. CB-75}

The MIC values of the crude extract from Streptomyces sp. CB75 were further determined against all tested pathogenic fungi using a 96-well microtiter assay. The MIC values of the crude extract were found within the range of $50-0.781 \mu \mathrm{g} / \mathrm{ml}$. The lowest inhibitory concentration of the crude extract against these fungi was assessed as the MIC. The lowest MIC was $0.781 \mu \mathrm{g} / \mathrm{ml}$ against C. musae (ATCC 96167), which showed the crude extract yielded a strong antifungal activity against this strain. However, the highest MIC was $50.0 \mu \mathrm{g} / \mathrm{ml}$ against C. gloeosporioides (ATCC 16330) (Table 4). The $10 \%$ DMSO control had no inhibitory effect on tested pathogenic fungi.

\section{Spore Germination Assay}

The effects of the crude extract of Streptomyces sp. CB-75 on spore germination of the tested pathogenic fungi are shown in Figure 3. The results show that spore germination was significantly different $(P<0.05)$ with different concentrations of the crude extract. The percentage of spore germination decreased with increasing concentration of the crude extract. The concentration of $8 \times$ MIC was most effective against spore germination (Table 5). The maximum percentage of spore germination inhibition was $93.96 \%$ against C. musae (ATCC 96167). The minimum percentage of spore germination inhibition was $83.12 \%$ against A. tenuissima (ATCC 26513). The $10 \%$ DMSO $(\mathrm{v} / \mathrm{v})$, as a control, did not inhibit the spore germination of the tested pathogenic fungi.

\section{SEM Analysis}

The effect of the crude extract of Streptomyces sp. CB-75 against F. oxysporum Race 4 (ATCC 76255) was confirmed by SEM
(Figure 4). SEM images of the cells treated with $2 \times$ MIC of the crude extract revealed considerable morphological alterations, including deformation, shrinkage, collapse, tortuosity, and broken cells, leading to prominent cell shape loss and integrity (Figures 4D-I). The control cells treated with 10\% DMSO were intact with smooth surfaces (Figures 4A-C).

\section{GC-MS Analysis}

From the GC-MS analysis, 18 chemical compounds of the crude extract of Streptomyces sp. CB-75 were identified by the National Institute of Standards and Technology (NIST) library based on their retention time, molecular mass, molecular formula (Table 6), and their chemical structures, listed in Figure 5. These compounds were methylguanidine (1), 2-phenylacetic acid (2), (E,E)-2,4-decadienal (3), dimethyl 2-(2-benzoylhydrazinyl)-2-hydroxypropanedioate (4), benzeneacetamide (5), 2,4-bis(1,1-dimethylethyl)-phenol (6), diethyl phthalate (7), nonadecane (8), hexadecanoic acid, methyl ester (9), 3-isobutylhexahydropyrrolo[1,2-a]pyrazine-1,4-dione (10), $n$-hexadecanoic acid (11), (Z,Z)-9,12-octadecadienoic acid (12), oleic acid (13), 7-methyl-Z-tetradecen-1-ol acetate (14), 13,13-dimethyltetradecane-1-thiol (15), hexadecanoic acid, 2-hydroxy-1-(hydroxymethyl) ethyl ester (16), 1,2-benzenedicarboxylic acid diisooctyl ester (17), and (Z)13-docosenamide (18). The peak area of the compounds was in direct proportion to their quantity in the crude extract of Streptomyces sp. CB-75 (Figure 5).

\section{Control Effects of Streptomyces sp. CB-75 Fermentation Broth on Banana Fusarium Wilt}

Fusarium wilt disease spread rapidly when plantlets were inoculated with a high concentration of F. oxysporum Race 4. However, there was no significant difference between the treatments and the control (Table 7). After 15 days, the infected plantlets were treated with the fermentation broth of CB-75. As time went on, plantlets began to die, and on the 60th day, fifteen 
TABLE 2 | Physiological and biochemical characteristics of Streptomyces sp. CB-75.

\begin{tabular}{|c|c|}
\hline Characteristic & Result \\
\hline \multicolumn{2}{|c|}{ BIOCHEMICAL TEST } \\
\hline Gelatin liquefaction & - \\
\hline Milk peptonization & - \\
\hline Milk solidification & - \\
\hline Nitrate reduction & + \\
\hline Amylolysis & + \\
\hline $\mathrm{H} 2 \mathrm{~S}$ & + \\
\hline Pigment & + \\
\hline Tyrosinase & - \\
\hline \multicolumn{2}{|c|}{ NITROGEN SOURCE UTILIZATION } \\
\hline L-Arginine & + \\
\hline L-Serine & - \\
\hline L-Phenylalanine & + \\
\hline Glycine & + \\
\hline Methionine & + \\
\hline L-Hydroxyproline & + \\
\hline$L(+)$-Cysteine & + \\
\hline L-Homocysteine & + \\
\hline Valine & + \\
\hline Histidine & + \\
\hline Ammonium nitrate & + \\
\hline Ammonium chloride & + \\
\hline \multicolumn{2}{|c|}{ CARBON-SOURCE UTILIZATION } \\
\hline$\alpha$-Lactose & + \\
\hline D-Cellobiose & + \\
\hline D-Fructose & + \\
\hline D-Galactose & + \\
\hline D-Glucose & + \\
\hline D-Mannose & + \\
\hline D-Sorbitol & + \\
\hline D-Trehalose & - \\
\hline D-Xylose & + \\
\hline L-Arabinose & + \\
\hline Melitose & + \\
\hline Melibiose & + \\
\hline Xylan & + \\
\hline D-Mannitol & + \\
\hline Inositol & - \\
\hline Melezitose & + \\
\hline Rhamnose & - \\
\hline Ribose & + \\
\hline Saligenin & + \\
\hline Soluble starch & + \\
\hline Sucrose & - \\
\hline
\end{tabular}

+, Positive reaction; -, Negative reaction.

plantlets were dead in the CK2 group, four plantlets were dead in the CK3 group, nine plantlets were dead in the A group, while there were no dead plantlets in the CK1 and $A B$ groups. The disease indices of CK2, CK3, and A were very high (CK2 was
81.38, CK3 was 53.81, A was 70.45). The prevention and control effect of CK3 was better (51.88\%). However, when the plantlets were treated with the CB-75 fermentation broth $(\mathrm{AB})$, the disease index was 10.23, and the prevention and control effect was the best $(83.12 \%)$.

\section{Effect of Streptomyces sp. CB-75 on Banana Chlorophyll Content}

As shown in Figure 6, with increasing transplanting period, the chlorophyll content of CK1 continued to rise, the chlorophyll content of CK2 showed a decreasing trend, but the chlorophyll content of the plants in the $\mathrm{CK} 3, \mathrm{~A}$, and $\mathrm{AB}$ treatment groups first decreased and then increased. The final value of $\mathrm{AB}$ treatment was the highest on the 60th day, and the rising trend was also significantly higher than that of the other treatments. The chlorophyll content was negatively correlated with the incidence index. The control effect in the CK1 group was lower, with 15 dead plantlets, and the chlorophyll content also decreased with the transplanting period increased. The chlorophyll content of CK3 and A showed an increasing trend, $0.81 \mathrm{mg} / \mathrm{g}$ and $0.68 \mathrm{mg} / \mathrm{g}$, respectively, but the final value was always lower than that of CK1 treatment. In the AB treatment group, due to the presence of bioactive compounds, the disease index of banana seedlings decreased in the latter stages, and the effect of disease prevention was significant. The chlorophyll content was $1.28 \mathrm{mg} / \mathrm{g}$ on the 60th day, which was significantly higher than for the other treatments. The chlorophyll content was 88.24\% compared with A treatment, and 33.33\% compared with CK1 treatment. This was indicative that the fermentation broth of CB-75 improved the chlorophyll content of banana plants.

\section{Effects of Streptomyces sp. CB-75 Fermentation Broth on the Growth of Banana Plants}

After 15 days, the banana seedlings were not significantly different for leaf area, root length, root diameter, plant height, and stem among the five treatments. After 45 days, banana seedlings were treated by the fermentation broth of CB-75, the leaf area was $1,398.13 \mathrm{~cm}^{2}$, root length was $1354.87 \mathrm{~cm}$, root diameter was $1.11 \mathrm{~mm}$, plant height was $53.76 \mathrm{~cm}$, and the stem was $6.19 \mathrm{~cm}$, which were significantly higher than for the other treatments (Table 7). The leaf area increased by $88.24 \%$, root length increased by $90.49 \%$, root diameter increased by $136.17 \%$, plant height increased by $61.78 \%$, and stem increased by $50.98 \%$ compared with treatment A. Thus, the fermentation broth of CB-75 not only had antifungal activity, but also had a growthpromoting effect on the banana seedlings. The fermentation broth promoted plant leaf area, enhanced photosynthesis, increased root growth, and promoted transpiration, thereby promoting banana plant growth and increasing yield. Wang et al. (2016) found that the Bacillus amyloliquefaciens strain W19 can promote the growth and fruit yield of banana, while suppressing the banana Fusarium wilt disease. Streptomycetes sp. K2 was isolated from strawberry field soils, and promoted the growth of strawberry plants and fruits (Eccleston et al., 2010). 


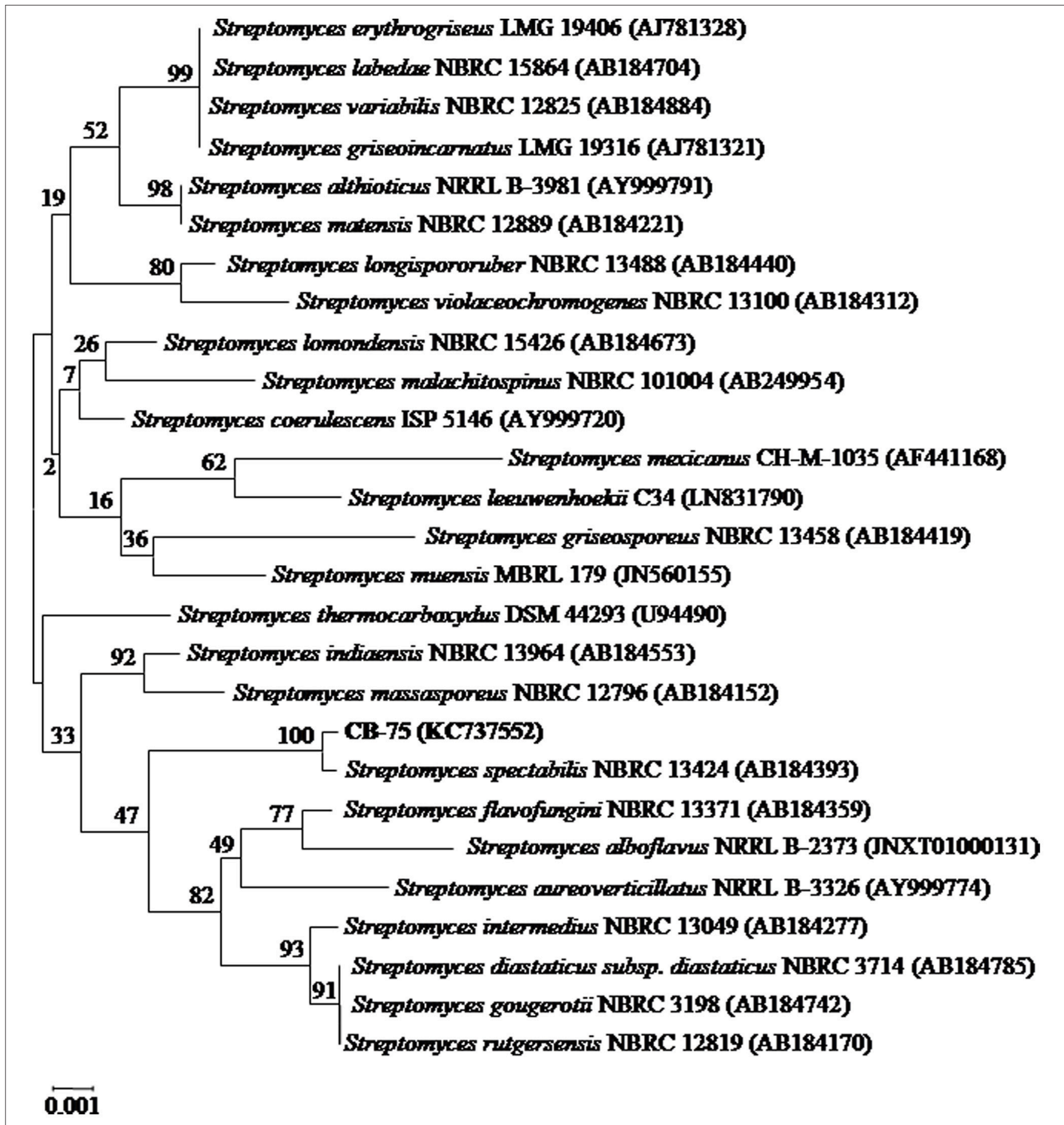

FIGURE 2 | Neighbor-joining phylogenetic tree based on almost complete 16S rRNA gene sequences (1,490 nucleotides) showing the phylogenetic relationship between strain Streptomyces sp. CB-75 and representatives of some other related taxa. Bootstrap percentages based on 1,000 resamplings are listed at nodes, only values above 50\% are shown. GenBank accession numbers are given in parentheses. Bar, 0.001 substitutions per nucleotide position.

Effect of Streptomyces sp. CB-75 on Banana

Biomass

The mean fresh weight and dry weight of plantlets was higher for those treated with Streptomyces sp. CB-75 compared with those in the other groups (Figure 7). Shoot weights (fresh and dry) was in the following order: $\mathrm{AB}>\mathrm{CK} 1>\mathrm{CK} 3>\mathrm{A}>\mathrm{CK} 2$. The weight for the $A B$ treatment group was significantly higher than for the other treatments, shoot fresh weight was $48.20 \mathrm{~g}$, shoot dry weight was 
TABLE 3 | Inhibitory action of Streptomyces sp. CB-75 against plant pathogenic fungal strains.

\begin{tabular}{lcc}
\hline Pathogenic fungal & $\begin{array}{c}\text { Inhibition zone } \\
\mathbf{( m m})\end{array}$ & $\begin{array}{c}\text { Mycelial inhibition } \\
\mathbf{( \% )}\end{array}$ \\
\hline F. oxysporum Race 1 (ATCC 76244) & $11.40 \pm 0.36 \mathrm{~d}$ & $73.11 \pm 0.80 \mathrm{~d}$ \\
F. oxysporum Race 4 (ATCC 76255) & $13.77 \pm 0.31 \mathrm{~b}$ & $78.37 \pm 0.68 \mathrm{~b}$ \\
C. gloeosporioides (ATCC 58222) & $13.50 \pm 0.50 \mathrm{~b}$ & $77.78 \pm 1.11 \mathrm{~b}$ \\
C. fragariae (ATCC 58718) & $12.83 \pm 0.29 \mathrm{c}$ & $76.30 \pm 0.64 \mathrm{c}$ \\
C. acutatum (ATCC 56815) & $14.43 \pm 0.40 \mathrm{a}$ & $79.85 \pm 0.90 \mathrm{a}$ \\
B. cinerea (ATCC 11542) & $13.23 \pm 0.25 \mathrm{bc}$ & $77.19 \pm 0.56 \mathrm{bc}$ \\
C. musae (ATCC 96167) & $14.93 \pm 0.35 \mathrm{a}$ & $80.96 \pm 0.78 \mathrm{a}$ \\
C. fallax (ATCC 38579) & $13.67 \pm 0.31 \mathrm{~b}$ & $78.15 \pm 0.68 \mathrm{~b}$ \\
C. gloeosporioides (ATCC MYA-456) & $13.23 \pm 0.38 \mathrm{bc}$ & $77.19 \pm 0.84 \mathrm{bc}$ \\
A. tenuissima (ATCC 26513) & $11.73 \pm 0.38 \mathrm{~d}$ & $73.85 \pm 0.84 \mathrm{~d}$ \\
C. gloeosporioides (ATCC 16330) & $12.70 \pm 0.36 \mathrm{c}$ & $76.00 \pm 0.80 \mathrm{c}$ \\
\hline
\end{tabular}

Data in the table are means $\pm S D$. Different lowercase letters in the same column show values that are significantly different at the $P<0.05$ level by Duncan's new multiple range test.

$4.34 \mathrm{~g}$, and water content was $90.99 \%$. There was no significant difference in root fresh weight between $\mathrm{AB}$ and $\mathrm{CK} 1$ treatments, which were significantly higher than for the others treatment. The root dry weight for the AB treatment group was significantly higher than for the other treatments; there was no significant difference in root dry weight between CK1 and CK3. The results showed that the dry matter accumulation increased significantly, and was higher than normal for the growth of banana seedlings treated with Streptomyces sp. CB-75. The shoot fresh weight increased by $82.38 \%$, the root fresh weight increased by $72.01 \%$, the shoot dry weight increased by $195.33 \%$, and the root dry weight increased by $113.33 \%$ compared with the treatment A group. Thus, the fermentation broth of Streptomyces sp. CB-75 had a growth-promoting effect on banana plants.

\section{DISCUSSION}

Plant diseases caused by pathogenic fungi bring about heavy losses in agriculture and result in a serious threat to global food security (Savary et al., 2006). Most losses of fruits and vegetables have been attributed to fungal pathogens, they often cause crops to rot, and sometimes produce mycotoxins that are harmful to animal and human health (Saremi and Okhovvat, 2006). F. oxysporum is a major pathogenic fungus that can cause postharvest decay in crops (Saremi and Okhovvat, 2006). Banana Fusarium wilt (caused by F. oxysporum) is a common plant disease that causes leaf blight; it is a devastating disease that causes significant economic damage to banana. However, the utilization of antagonistic microorganisms within the soil can effectively control the growth and reproduction of the pathogen (Deng et al., 2013). The biological control of plant diseases has become a focus of research due to its high efficiency, broad spectrum, and environmental friendliness, and because it will not cause plant pathogen resistance. However, the correct isolation and application of biocontrol microorganisms is a key factor
TABLE 4 | MIC values $(\mu \mathrm{g} / \mathrm{ml})$ from the microtiter assay for Streptomyces sp. CB-75 by broth dilution method.

\begin{tabular}{lccc}
\hline Pathogenic fungi & $\begin{array}{c}\text { MIC of } \\
\text { CB-75 }(\boldsymbol{\mu} \mathbf{g} / \mathbf{m l})\end{array}$ & $\begin{array}{c}\text { MIC of } \\
\mathbf{C y}(\boldsymbol{\mu} \mathbf{g} / \mathbf{m l})\end{array}$ & $\begin{array}{c}\text { MIC of } \\
\mathbf{A z}(\boldsymbol{\mu} \mathbf{g} / \mathbf{m l})\end{array}$ \\
\hline F. oxysporum Race 1 (ATCC 76244) & $>6.25$ & $>6.25$ & $>12.5$ \\
F. oxysporum Race 4 (ATCC 76255) & $>3.125$ & $>6.25$ & $>25.0$ \\
C. gloeosporioides (ATCC 58222) & $>1.563$ & $>3.125$ & $>3.125$ \\
C. fragariae (ATCC 58718) & $>6.25$ & $>6.25$ & $>6.25$ \\
C. acutatum (ATCC 56815) & $>3.125$ & $>0.781$ & $>1.563$ \\
B. cinerea (ATCC 11542) & $>1.563$ & $>12.5$ & $>6.25$ \\
C. musae (ATCC 96167) & $>0.781$ & $>1.563$ & $>3.125$ \\
C. fallax (ATCC 38579) & $>3.125$ & $>3.125$ & $>6.25$ \\
C. gloeosporioides (ATCC MYA-456) & $>12.5$ & $>12.5$ & $>25.0$ \\
A. tenuissima (ATCC 26513) & $>12.5$ & $>12.5$ & $>12.5$ \\
C. gloeosporioides (ATCC16330) & $>50.0$ & $>25.0$ & $>50.0$ \\
\hline
\end{tabular}

Cy, Cycloheximide (antifungal agent); Az, Azoxystrobin (antifungal agent).

in biological control (Chaves et al., 2011). Research shows that biofertilizer can effectively prevent plant diseases, which may be due to the presence of antagonistic microbes that become the dominant population in the micro-environment, so as to give full play to the antibacterial or bactericidal effect (Swain and Ray, 2009). Therefore, isolation and screening of highly efficient antagonistic microorganisms is the key to the development of biocontrol reagents.

Actinomycetales, especially Streptomyces strains, have a unique and proven capacity to produce novel antibiotics, and these species have great practical value (Hong et al., 2009). The actinomycetales Streptomyces sp. CB-75 was isolated using the spread plate method from the soil of a diseased banana plantation. By using 16s rRNA sequence analysis, combined with morphological, culture, physiological, and biochemical characteristics, the results showed that strain Streptomyces sp. CB-75 exhibited the highest similarity to the strain Streptomyces spectabilis NBRC 13424 (Spasova et al., 1997).

Actinomycetes produce a wide range of bioactive secondary metabolites that are known to have anti-inflammatory, antimalarial, antifungal, antibacterial, antialgal, and anticancer activities. Approximately two-thirds of available antibiotics have been isolated from actinomycetes (Wang J. J. et al., 2015). The antibiotic oligomycin A was isolated from Streptomyces diastatochromogenes, and was found to be active against several phytopathogenic fungi, such as Botrytis cinerea, Cladosporium cucumerinum, Colletotrichum lagenarium, Phytophthora capsici, Alternaria alternata, and Aspergillus niger (Smith et al., 1954; Kim et al., 1999; Yang et al., 2010). An antagonistic compound was isolated from Streptomyces sp. TP-A0595 and identified as 6-prenylindole, with suppressive effect on infection by Alternaria brassicicola by inhibiting the formation of infection hyphae (Sasaki et al., 2002). Two compounds were purified from Streptomyces sp. 3-10, and were identified as reveromycins $\mathrm{A}$ and $\mathrm{B}$, which demonstrated high antifungal activity against Botrytis cinerea, Mucor hiemalis, Rhizopus stolonifer, and Sclerotinia sclerotiorum (Lyu et al., 


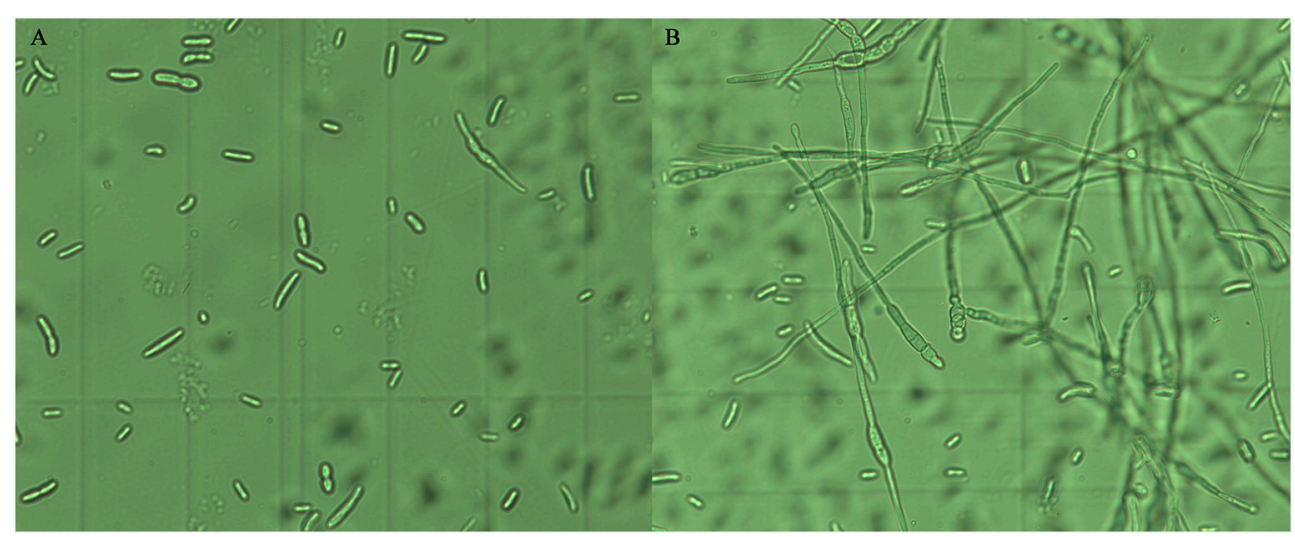

FIGURE 3 | Inhibition effect of the crude extract of Streptomyces sp. CB-75 on spore germination of F. oxysporum Race 4 (ATCC 76255 ). (A) Treatment with the crude extract of Streptomyces sp. CB-75; (B) without treatment.

TABLE 5 | The impact of the crude extract of Streptomyces sp. CB-75 on spore germination of the test pathogenic fungi.

\begin{tabular}{|c|c|c|c|c|}
\hline \multirow[t]{2}{*}{ Pathogenic fungi } & \multicolumn{4}{|c|}{ Inhibition of spore germination (\%) } \\
\hline & $1 \times \mathrm{MIC}$ & $2 \times \mathrm{MIC}$ & $4 \times \mathrm{MIC}$ & $8 \times \mathrm{MIC}$ \\
\hline F. oxysporum Race 1 (ATCC 76244) & $44.97 \pm 0.88 \mathrm{~g}$ & $66.37 \pm 1.24 \mathrm{~h}$ & $75.62 \pm 0.91 \mathrm{~g}$ & $86.13 \pm 1.11 \mathrm{~g}$ \\
\hline F. oxysporum Race 4 (ATCC 76255) & $55.23 \pm 1.76 b$ & $69.95 \pm 1.01 \mathrm{c}$ & $79.57 \pm 1.07 b$ & $91.37 \pm 0.81 c$ \\
\hline C. gloeosporioides (ATCC 58222) & $55.24 \pm 1.62 b$ & $69.67 \pm 0.84 c$ & $79.45 \pm 0.92 b$ & $91.22 \pm 1.34 \mathrm{c}$ \\
\hline C. fragariae (ATCC 58718) & $53.91 \pm 1.35 c$ & $67.35 \pm 0.72 f$ & $76.74 \pm 0.72 \mathrm{e}$ & $90.20 \pm 1.03 d$ \\
\hline C. acutatum (ATCC 56815) & $54.20 \pm 1.45 c$ & $68.61 \pm 1.15 d$ & $78.80 \pm 0.95 c$ & $93.43 \pm 0.95 b$ \\
\hline B. cinerea (ATCC 11542) & $52.95 \pm 1.39 d$ & $66.82 \pm 0.86 \mathrm{~g}$ & $77.10 \pm 0.73 d$ & $89.63 \pm 1.18 \mathrm{e}$ \\
\hline C. musae (ATCC 96167) & $57.48 \pm 1.50 \mathrm{a}$ & $73.30 \pm 1.15 a$ & $81.25 \pm 0.97 \mathrm{a}$ & $93.96 \pm 0.99 a$ \\
\hline C. fallax (ATCC 38579) & $52.85 \pm 0.98 d$ & $71.09 \pm 0.74 b$ & $78.58 \pm 1.40 c$ & $87.14 \pm 0.93 f$ \\
\hline C. gloeosporioides (ATCC MYA-456) & $46.27 \pm 0.98 f$ & $67.87 \pm 1.03 e$ & $70.95 \pm 1.03 i$ & $84.25 \pm 0.80 h$ \\
\hline A. tenuissima (ATCC 26513) & $39.26 \pm 0.79 h$ & $60.27 \pm 1.40 i$ & $73.01 \pm 0.85 h$ & $83.12 \pm 1.16 \mathrm{i}$ \\
\hline C. gloeosporioides (ATCC 16330) & $48.28 \pm 1.25 e$ & $67.53 \pm 1.08$ ef & $76.26 \pm 1.11 \mathrm{f}$ & $87.22 \pm 0.75 f$ \\
\hline
\end{tabular}

Data in the table are means $\pm S D$. Different lowercase letters in the same column show values that are significantly different at the $P<0.05$ level by Duncan's new multiple range test.

2017). Srivastava et al. found Chrestomyceticus could produce metabolites with antifungal activity against Candida albicans (Srivastava and Dubey, 2016). Nguyen et al. isolated a monomer compound from Streptomyces griseus $\mathrm{H} 7602$ with strong inhibitory activity against Phytophthora capsici, and the antibacterial mechanism was studied (Nguyen et al., 2015). Some well-known antibiotics produced by Streptomyces have been used as fungicides. For instance, blasticidin-S was isolated from Streptomyces griseochromogenes and was an antibiotic commercially introduced for the control of rice blast in Japan (Fukunaga et al., 1955; Tapadar and Jha, 2013). Streptomyces spectabilis can produce many types of antibiotics with high antibacterial activity, including spectinomycin (Kim et al., 2008), streptovaricin (Kakinuma et al., 1976), and desertomycin (Ivanova, 1997), and has a high application value in the pharmaceutical industry (Selvakumar et al., 2015). However, there are no reports on its activity against soil-borne plant diseases and it isn't currently used in agriculture. The discovery of this Streptomyces strain provides new products for the pharmaceutical industry, but also provides a method for the control of plant diseases, and lays the foundation for future agricultural studies. In the future, the extraction and purification of the antifungal metabolites will be studied, and the antifungal mechanism will be improved and perfected.

Biosynthetic gene clusters are responsible for microbial natural product biosynthesis. Polyketides and non-ribosomal peptides are a structurally varied group of compounds, and play important biological roles (Nimaichand et al., 2015). The genes encoding PKS-I and NRPS might both play a part in the production of antifungal activity from Streptomyces sp. CB-75. The results were similar to the studies of Sharma et al. (2016) and Passari et al. (2015), and it was shown that actinomycetes possessing antifungal activity were positive for the presence of both of these two biosynthetic pathway genes in their genomes. The presence of genes encoding PKS-I and NRPS in strain CB-75 is indicative of the possibility that it can produce bioactive secondary metabolites belonging to these two classes of natural products, or a hybrid of both (Dhaneesha et al., 2017). Relatively low sequence similarity of the PKS-I gene sequences $(84 \%)$ with those available in GenBank is indicative of the 


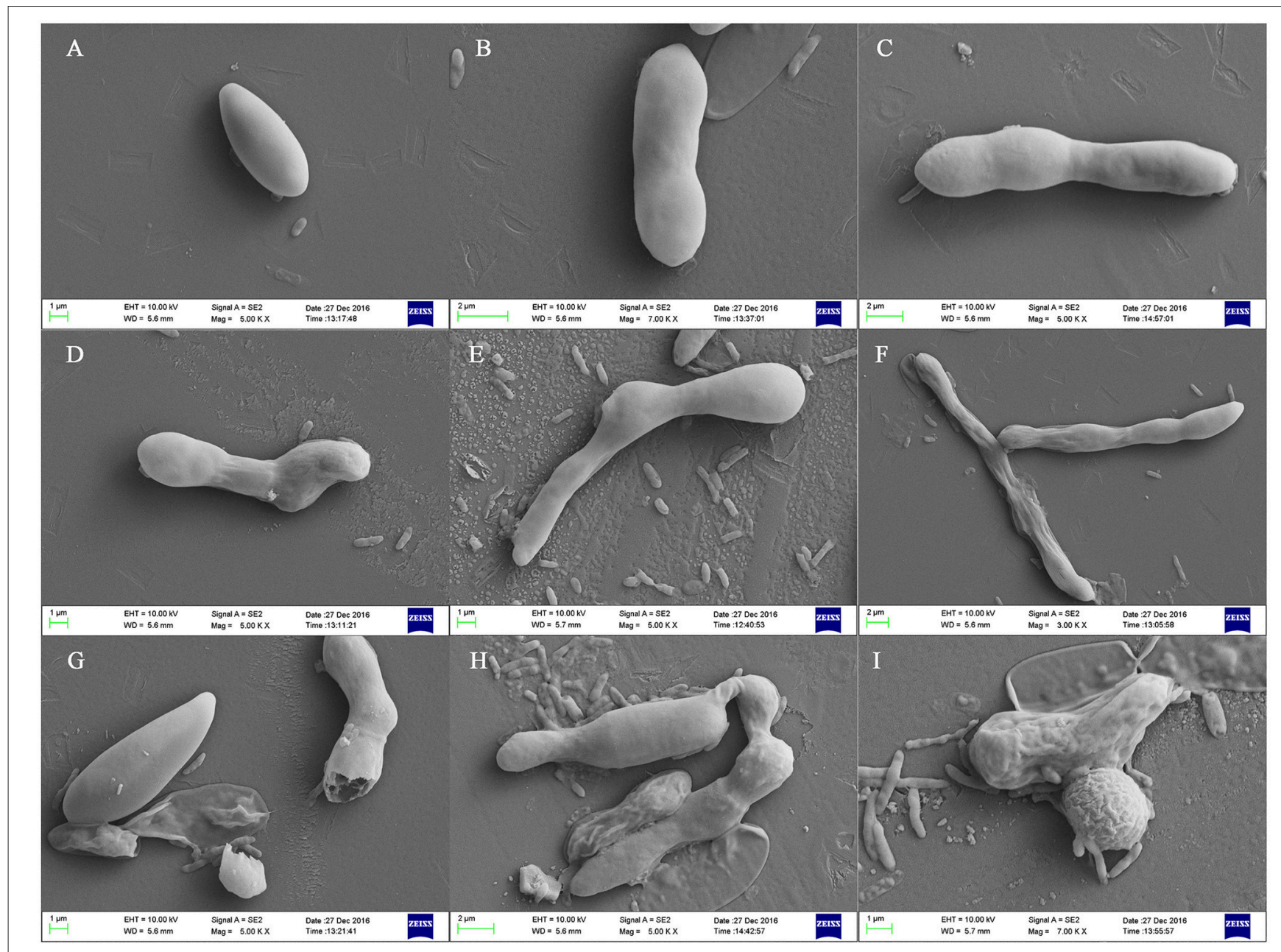

FIGURE 4 | Scanning electron micrographs of F. oxysporum Race 4 (ATCC 76255) treated with the crude extract of Streptomyces sp. CB-75. (A-C) Treatment with 10\% DMSO, (D-I) treatment with the crude extract of Streptomyces sp. CB-75.

possibility that novel compounds are produced by Streptomyces sp. CB-75.

GC-MS is a powerful analytical tool for the chemical analysis of microbial metabolites (Ser et al., 2015a,b; Tan et al., 2015). GC-MS plays a significant role in natural product discovery, including bioactive compounds derived from Streptomyces species (Ara et al., 2014; Jog et al., 2014). Ser et al. (2015a) reported the detection of an antioxidative bioactive compound, 3-Isobutylhexahydropyrrolo[1,2-a]pyrazine-1,4-dione, in an extract of Streptomyces mangrovisoli sp. nov., and Kim et al. (2008) found protocatechualdehyde in an Streptomyces lincolnensis M-20 extract using GC-MS. GC-MS analysis was performed on a crude extract of Streptomyces sp. CB-75, and 18 chemical compounds were found with different retention times and relative abundances. The compounds present included an alkaloid, polymeric aldehyde, hydrocarbons, acids, terpenoids, phenolic, esters, and quinones. Methyl-guanidine is a known nephrotoxin and neurotoxin, and increases oxidative metabolism and accelerates apoptosis of neutrophils (Noda et al., 2016; Bosco et al., 2017). 2-Phenylacetic acid was found to have effective antibacterial activity against Escherichia coli and Ralstonia solanacearum (Zhu et al., 2011). (E,E)-2,4-Decadienal exhibited strong paralytic activity on second-stage Meloidogyne incognita, Meloidogyne javanica and Meloidogyne arenaria juveniles (Ntalli et al., 2016). Guan et al. (2016) reported benzeneacetamide as an antidepressant-like and anticonvulsant compound. Phenolic compounds were alluded to as potent antimicrobial agents, as are free radical terminators, as they possess hydrogen-donating capability to reduce free radicals (Yogeswari et al., 2012). Recently, a study conducted by Kumar P. S. et al. (2014) showed high antimicrobial activity in the GC-MS fractions containing the highest amounts of phenolic compounds. Phenolic compounds, such as 2,4-bis(1,1-dimethylethyl)-phenol, were detected in CB-75. Hexadecanoic acid methyl ester has been reported to cause autolysis of membranous structures, induce significant aortic dilation, inhibit phagocytic activity and nitric oxide production of certain cells, reduce levels of tumor necrosis, and was isolated from the Hibiscus sabdariffa Linn (Ajoku 
TABLE 6 | Compounds identified from the crude extract of Streptomyces sp. CB-75 through GC-MS.

\begin{tabular}{|c|c|c|c|c|c|c|c|}
\hline Compound name & Probability (\%) & RT (min) & MM & Area (\%) & MF & Activity & References \\
\hline Methyl-guanidine & 58.00 & 7.52 & 73 & 0.65 & $\mathrm{C}_{2} \mathrm{H}_{7} \mathrm{~N}_{3}$ & Cytotoxic & Bosco et al., 2017 \\
\hline 2-Phenylacetic acid & 57.31 & 16.64 & 136 & 6.67 & $\mathrm{C}_{8} \mathrm{H}_{8} \mathrm{O}_{2}$ & Antimicrobial & Zhu et al., 2011 \\
\hline$(E, E)-2,4-D e c a d i e n a l$ & 33.67 & 18.46 & 152 & 0.35 & $\mathrm{C}_{10} \mathrm{H}_{16} \mathrm{O}$ & Nematicidal & Ntalli et al., 2016 \\
\hline $\begin{array}{l}\text { Dimethyl 2-(2-benzoylhydrazinyl)-2- } \\
\text { hydroxypropanedioate }\end{array}$ & 88.01 & 18.94 & 282 & 0.47 & $\mathrm{C}_{12} \mathrm{H}_{14} \mathrm{~N}_{2} \mathrm{O}_{6}$ & No activity reported & \\
\hline Benzeneacetamide & 75.89 & 20.09 & 135 & 5.08 & $\mathrm{C}_{8} \mathrm{Hg}_{9} \mathrm{NO}$ & Antidepressant Anticonvulsant & Guan et al., 2016 \\
\hline 2,4-Bis(1,1-dimethylethyl)-phenol & 33.06 & 21.74 & 206 & 0.49 & $\mathrm{C}_{14} \mathrm{H}_{22} \mathrm{O}$ & No activity reported & \\
\hline Diethyl phthalate & 68.10 & 22.98 & 222 & 0.51 & $\mathrm{C}_{12} \mathrm{H}_{14} \mathrm{O}_{4}$ & No activity reported & \\
\hline Nonadecane & 21.70 & 24.12 & 268 & 0.62 & $\mathrm{C}_{19} \mathrm{H}_{40}$ & No activity reported & \\
\hline Hexadecanoic acid, methyl ester & 33.31 & 26.65 & 270 & 1.21 & $\mathrm{C}_{17} \mathrm{H}_{34} \mathrm{O}_{2}$ & Antioxidant & Ajoku et al., 2015 \\
\hline $\begin{array}{l}\text { 3-Isobutylhexahydropyrrolo[1,2- } \\
\text { a]pyrazine-1,4-dione }\end{array}$ & 36.39 & 26.91 & 210 & 1.71 & $\mathrm{C}_{11} \mathrm{H}_{18} \mathrm{~N}_{2} \mathrm{O}_{2}$ & Antioxidant & Ser et al., 2015a \\
\hline$n$-Hexadecanoic acid & 60.58 & 27.03 & 256 & 5.21 & $\mathrm{C}_{16} \mathrm{H}_{32} \mathrm{O}_{2}$ & Antibacterial & Johannes et al., 2016 \\
\hline$(Z, Z)-9,12-O c t a d e c a d i e n o i c ~ a c i d$ & 16.08 & 28.75 & 280 & 5.78 & $\mathrm{C}_{18} \mathrm{H}_{32} \mathrm{O}_{2}$ & No activity reported & \\
\hline Oleic acid & 30.93 & 28.95 & 282 & 10.02 & $\mathrm{C}_{18} \mathrm{H}_{34} \mathrm{O}_{2}$ & No activity reported & \\
\hline 7-Methyl-Z-tetradecen-1-ol acetate & 11.09 & 29.12 & 268 & 1.64 & $\mathrm{C}_{17} \mathrm{H}_{32} \mathrm{O}_{2}$ & No activity reported & \\
\hline 13,13-Dimethyltetradecane-1-thiol & 17.38 & 29.20 & 258 & 4.04 & $\mathrm{C}_{16} \mathrm{H}_{34} \mathrm{~S}$ & No activity reported & \\
\hline $\begin{array}{l}\text { Hexadecanoic acid, } \\
\text { 2-hydroxy-1-(hydroxymethyl) ethyl ester }\end{array}$ & 60.79 & 33.55 & 330 & 0.88 & $\mathrm{C}_{19} \mathrm{H}_{38} \mathrm{O}_{4}$ & $\begin{array}{l}\text { Antioxidant, anti-inflammatory, } \\
\text { anthelmintic }\end{array}$ & Al-Marzoqi et al., 2015 \\
\hline $\begin{array}{l}\text { 1,2-Benzenedicarboxylic acid diisooctyl } \\
\text { ester }\end{array}$ & 58.19 & 33.85 & 390 & 0.75 & $\mathrm{C}_{24} \mathrm{H}_{38} \mathrm{O}_{4}$ & Antifungal & $\begin{array}{l}\text { Rahman and Anwar, } \\
2006\end{array}$ \\
\hline (Z)-13-Docosenamide & 50.95 & 40.64 & 337 & 53.26 & $\mathrm{C}_{22} \mathrm{H}_{43} \mathrm{NO}$ & Antiviral & Donio et al., 2013 \\
\hline
\end{tabular}

RT, Retention time; MM, Molecular mass of compound; MF, Molecular formula.

et al., 2015). According to recent reports by Ser et al. (2015a), 3-Isobutylhexahydropyrrolo[1,2-a]pyrazine-1,4-dione exhibited strong antioxidant activity and was useful as a preventive agent against free-radical-associated diseases. Hexadecanoic acid was shown to have antibacterial activity by damaging the cell walls of Salmonella typhi (Johannes et al., 2016). Al-Marzoqi et al. (2015) reported antioxidant, anti-inflammatory and anthelmintic activities of hexadecanoic acid, 2-hydroxy-1-(hydroxymethyl) ethyl ester. 1,2-Benzenedicarboxylic acid diisooctyl ester, isolated from the roots of Plumbago zeylanica was screened for its antifungal activity against six phytopathogenic fungi (Rahman and Anwar, 2006). Another study conducted by Donio et al. (2013) illustrated that (Z)-13-docosenamide isolated from halophilic Bacillus sp. BS3 possesses strong antiviral activity. These compounds are well recognized for their antifungal activity and together they may be responsible for the broadspectrum antifungal activity of CB-75 against the wide range of test fungal pathogens. Previous reports by Sharma et al. (2016), Tan et al. (2015), and Ser et al. (2015a,b) showed the common effect of bioactive compounds from GC-MS analysis. Thus, we propose that these compounds could be the key contributing factors to the antifungal activities of CB-75. The study of other biological activities of the metabolites produced by strain $\mathrm{CB}-75$ is the subject of further investigation.

In recent years, the research of actinomycetes was focused on its ability to control plant disease and indirectly promote plant growth. Most isolates in the genus Streptomyces showed surpassing antifungal activities against fungal pathogens, and abilities to produce plant-growth-promoting agents in high quantity (Himaman et al., 2016). Actinomycetes could provide nutrients by the specific uptake system to stimulate plant growth (Rungin et al., 2012). Mahadevan and Crawford (1997) found Streptomyces olivaceoviridis, Streptomyces rimosus, Streptomyces rochei, Streptomyces griseoviridis, and Streptomyces lydicus had the ability to improve plant growth by increasing seed germination, root elongation, and root dry weight. Uphoff et al. (2009) reported Streptomyces strains significantly enhanced plant growth by increasing plant root length, number of roots, plant shoot length, number of leaves, fresh weight, and dry weight over the un-inoculated control. Almost all the rhizospheric actinomycetes were also able to produce ammonia and hydrogen cyanide (Anwar et al., 2016). Marques et al. (2010) found that bacteria could synthesize ammonia and supply nitrogen to the host plant. Furthermore, overproduction of ammonia serves as an inhibition factor for the plant pathogens. Ammonia and hydrogen cyanide production also play an important role in suppression of plant disease. Hastuti et al. (2012) reported Streptomyces sp. LSW05 can produce hydrogen cyanide. Anwar et al. (2016) found that Streptomyces kunmingensis WC-3, Streptomyces enissocaesilis TA-3, Streptomyces sp. WA1, and Streptomyces djakartensis TB-4 could produce ammonia and hydrogen cyanide. These rhizospheric Streptomyces were good candidates to be developed as biofertilizers for growth promotion and yield enhancement in crops, and could be exploited for the commercial production of different agro-active compounds. The study had demonstrated for the first time, 
<smiles>CN=C(N)N</smiles>

(1)<smiles>NC(=O)Cc1ccccc1</smiles>

(5)<smiles>CCOC(=O)c1ccccc1C(=O)OCC</smiles>

(7)<smiles>O=C(O)Cc1ccccc1</smiles>

(2)<smiles>CCCCC/C=C/C=C/C=O</smiles>

(3)<smiles>COC(=O)C(O)(NNC(=O)c1ccccc1)C(=O)OC</smiles>

(4)<smiles>CC(C)(C)c1ccc(O)c(C(C)(C)C)c1</smiles>

(6)<smiles>CCCCCCCCCCCCCCCCCCC</smiles>

(9)<smiles>CCCCCCCCCCCCCCCC(=O)O</smiles>

(11)<smiles>CCCCC/C=C/C/C=C/CCCCCCCC(=O)O</smiles>

(12)

(10)<smiles>CCCCCCCC/C=C/CCCCCCCC(=O)O</smiles>

(13)<smiles>CC(C)CCCCC(C)CO</smiles><smiles>CC(C)CCCCCOC(=O)c1ccccc1C(=O)I</smiles>

(17)

(16)<smiles>CCCCCCCC/C=C/CCCCCCCCCCCC(N)=O</smiles>

(18)

TABLE 7 | Effects of Streptomyces sp. CB-75 on banana Fusarium wilt and the growth of banana plantlets.

\begin{tabular}{|c|c|c|c|c|c|c|c|}
\hline Treatment & Disease index & $\begin{array}{l}\text { Control effect } \\
\text { (\%) }\end{array}$ & $\begin{array}{l}\text { Leaf area } \\
\text { (cm²/plant) }\end{array}$ & $\begin{array}{l}\text { Root length } \\
\text { (cm) }\end{array}$ & $\begin{array}{l}\text { Root diameter } \\
\text { (mm) }\end{array}$ & $\begin{array}{l}\text { Plant height } \\
\text { (cm) }\end{array}$ & $\begin{array}{l}\text { Stem } \\
(\mathrm{cm})\end{array}$ \\
\hline CK1 & - & 100 & $1,031.55 \pm 18.82 \mathrm{c}$ & $1,000.12 \pm 19.74 c$ & $0.66 \pm 2.13 c$ & $50.98 \pm 4.07 b$ & $5.71 \pm 0.88 b$ \\
\hline CK3 & $53.81 \pm 1.85 c$ & 51.88 & $1,155.42 \pm 20.08 b$ & $1,036.92 \pm 18.66 b$ & $0.78 \pm 1.98 b$ & $46.22 \pm 3.86 c$ & $4.97 \pm 0.97 c$ \\
\hline A & $70.45 \pm 2.33 b$ & 10.45 & $884.77 \pm 23.14 \mathrm{~d}$ & $711.25 \pm 20.45 d$ & $0.47 \pm 2.01 \mathrm{~d}$ & $33.23 \pm 5.32 d$ & $4.10 \pm 0.58 c$ \\
\hline
\end{tabular}

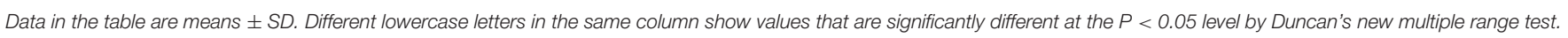




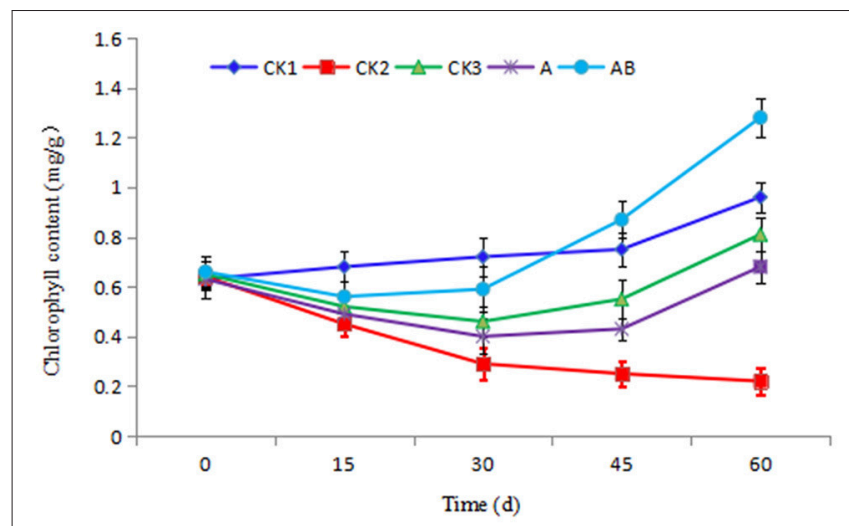

FIGURE 6 | Effect of Streptomyces sp. CB-75 on banana chlorophyll content.

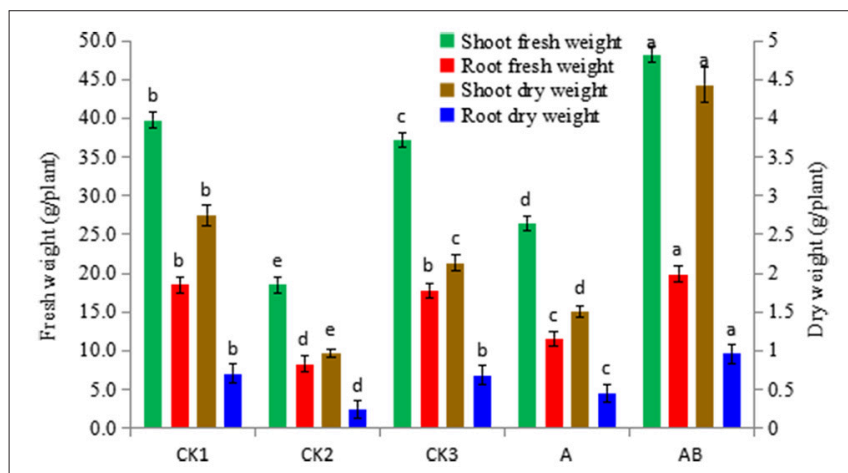

FIGURE 7 | Effect of Streptomyces sp. CB-75 on banana fresh weight and dry weight. Different lowercase letters $(a, b, c, d, e)$ in the figure indicate a significant difference at the $P<0.05$ level by Duncan's new multiple range test.

to our knowledge, that the selected Streptomyces sp. CB-75 had strong antagonistic ability against $F$. oxysporum by pot experiments. This strain had a good control effect on banana Fusarium wilt (83.12\%). It could increase banana leaf area, root length, root diameter, plant height, stem, and biomass. The findings from this current study are clearly indicative of the possibilities of using Streptomyces sp. as a bio-inoculant for growth promotion, nutrient mobilization, and biocontrol in banana seedling production.

\section{CONCLUSION}

During the exploration of antagonistic actinomycete predominant in soil samples of a diseased banana plantation in Hainan, China, Streptomyces sp. CB-75 was isolated by serial dilution technique. Based on phenotypic and molecular characteristics, and $99.93 \%$ sequence similarity with Streptomyces spectabilis NBRC 13424 (AB184393), the strain was identified as Streptomyces sp. This strain exhibited broad-spectrum antifungal activity against 11 plant pathogenic fungi. Type I polyketide synthase (PKS-I) and non-ribosomal peptide synthetase
(NRPS) were detected, which were indicative of the antifungal compounds that Streptomyces sp. CB-75 could produce. An ethyl acetate extract from the strain exhibited the lowest minimum inhibitory concentration (MIC) against Colletotrichum musae (ATCC 96167) $(0.78 \mu \mathrm{g} / \mathrm{ml})$ and yielded the highest antifungal activity against Colletotrichum gloeosporioides (ATCC 16330) $(50.0 \mu \mathrm{g} / \mathrm{ml})$. Also, spore germination was significantly inhibited by the crude extract. After treatment with the crude extract of Streptomyces sp. CB-75 at the concentration $2 \times \mathrm{MIC}$, the pathogenic fungi showed deformation, shrinkage, collapse, and tortuosity when observed by scanning electron microscopy (SEM). By gas chromatography-mass spectrometry (GC-MS) of the crude extract, 18 chemical constituents were identified; $(Z)$ 13-docosenamide was the major constituent. Pot experiments showed that the incidence of banana seedlings was reduced after using Streptomyces sp. CB-75 treatment. The disease index was 10.23, and the prevention and control effect was $83.12 \%$. Furthermore, Streptomyces sp. CB-75 had a growthpromoting effect on banana plants. The chlorophyll content showed $88.24 \%$ improvement, the leaf area, root length, root diameter, plant height, and stem showed 88.24, 90.49, 136.17, 61.78 , and $50.98 \%$ improvement, respectively, and the shoot fresh weight, root fresh weight, shoot dry weight, and root dry weight showed 82.38, 72.01, 195.33, and $113.33 \%$ improvement, respectively, compared with treatment of fermentation broth without Streptomyces sp. CB-75. Thus, Streptomyces sp. CB-75 is an important microbial resource as a biological control against plant pathogenic fungi and for promoting banana growth. From the results, it is obvious that Streptomyces sp. CB-75 is a promising candidate for the development of potential antifungal biocontrol agents against a wide range of fungal pathogens, and could be exploited as a fungicide to control plant fungal diseases. Moreover, more work is needed to optimize formulation, fermentation conditions, and application methods of Streptomyces sp. CB-75, in order to fully maximize its potential as an effective agent for controlling plant diseases.

\section{AUTHOR CONTRIBUTIONS}

YC and YL designed the research. YL and JX supervised the research work and guided the experimental design. DZ provided the suggestion of the research work. YC, DZ, ZG, and DQ were involved in soil sampling, DNA extraction, and amplification. YC and DZ conducted the other experiments. YC analyzed the data and was involved with writing the paper. YC and YL prepared the manuscript.

\section{FUNDING}

This project was funded by the China Agriculture Research System (CARS-32), the National NSFC (31760526), and Central Public-Interest Scientific Institution Basal Research Fund for the Chinese Academy of Tropical Agricultural Sciences (no. 1630052016005). 


\section{ACKNOWLEDGMENTS}

We thank Dandan Han for providing help, and the following individuals for their opinions and technical assistance: Xiyan Zhang, Renjun Feng, Fei Wang, Miaoyi Zhang, Tianyan Yun,

\section{REFERENCES}

Ajoku, G. A., Okwute, S. K., and Okogun, J. I. (2015). Isolation of hexadecanoic acid methyl ester and 1,1,2-ethanetricarboxylic acid- 1-hydroxy-1, 1-dimethyl ester from the calyx of green Hibiscus Sabdariffa (Linn). Nat. Prod. Chem. Res. 3, 169-173. doi: 10.4172/2329-6836.1000169

Albuquerque, C. C., Camara, T. R., Mariano, R. L. R., Willadino, L., Marcelino, J. C., and Ulisses, C. (2006). Antimicrobial action of the essential oil of Lippia gracillis Schauer. Braz. Arch. Biol. Technol. 49, 527-535. doi: 10.1590/S1516-89132006000500001

Almaguer, M., Rojas, T. I., Rodríguez-Rajo, F. J., and Aira, M. J. (2012). Airborne fungal succession in a rice field of Cuba. Eur. J. Plant Pathol. 133, 473-482. doi: 10.1007/s10658-011-9921-0

Al-Marzoqi, A. H., Hameed, I. H., and Idan, S. A. (2015). Analysis of bioactive chemical components of two medicinal plants (Coriandrum sativum and Melia azedarach) leaves using gas chromatography-mass spectrometry (GC-MS). Afr. J. Biotechnol. 14, 2812-2830. doi: 10.5897/AJB2015.14956

Anwar, S., Ali, B., and Sajid, I. (2016). Screening of rhizospheric actinomycetes for various in-vitro and in-vivo plant growth promoting (PGP) traits and for agroactive compounds. Front. Microbiol. 7:1334. doi: 10.3389/fmicb.2016.01334

Ara, I., Bukhari, N. A., Aref, N., Shinwari, M. M., and Bakir, M. (2014). Antiviral activities of streptomycetes against tobacco mosaic virus (TMV) in Datura plant: evaluation of different organic compounds in their metabolites. Afr. J. Biotechnol. 11, 2130-2138. doi: 10.5897/AJB11.3388

Ashokvardhan, T., and Satyaprasad, K. (2016). Antibacterial activity of actinomycetes isolated from capsicum annuuml. Int. J. Pharm. Bio. Sci. 7, 397-402.

Ashokvardhan, T., Rajithasri, A. B., Prathyusha, P., and Satyaprasad, K. (2014). Actinomycetes from Capsicum annuum L. Rhizosphere soil have the biocontrol potential against pathogenic fungi. Int. J. Curr. Microbiol. App. Sci. 3, 894-903.

Ayyadurai, N., Ravindra, N. P., Sreehari, R. M., Sunish, K. R., Samrat, S. K., Manohar, M., et al. (2006). Isolation and characterization of a novel banana rhizosphere bacterium as fungal antagonist and microbial adjuvant in micropropagation of banana. J. Appl. Microbiol. 100, 926-937. doi: $10.1111 /$ j.1365-2672.2006.02863.x

Bizuye, A., Moges, F., and Andualem, B. (2013). Isolation and screening of antibiotic producing actinomycetes from soils in Gondar town, North West Ethiopia. Asian Pac. J. Trop. Dis. 3, 375-381. doi: 10.1016/S2222-1808(13)60087-0

Bosco, A. M., Almeida, B. F., Pereira, P. P., Dos Santos, D. B., Neto, Á. J., Ferreira, W. L., et al. (2017). The uremic toxin methylguanidine increases the oxidative metabolism and accelerates the apoptosis of canine neutrophils. Vet. Immunol. Immunopathol. 185, 14-19. doi: 10.1016/j.vetimm.2017.01.006

Bressan, W. (2003). Biological control of maize seed pathogenic fungi by use of actinomycetes. BioControl 48, 233-240. doi: 10.1023/A:1022673226324

Cao, L. X., Qiu, Z. Q., You, J. L., Tan, H. M., and Zhou, S. (2005). Isolation and characterization of endophytic streptomycete antagonists of Fusarium wilt pathogen from surface-sterilized banana roots. FEMS Microbiol. Lett. 247, 147-152. doi: 10.1016/j.femsle.2005.05.006

Chaiharn, M., Chunhaleuchanon, S., and Lumyong, S. (2009). Screening siderophore producing bacteria as potential biological control agent for fungal rice pathogens in Thailand. World J. Microbiol. Biotechnol. 25, 1919-1928. doi: 10.1007/s11274-009-0090-7

Chaves, J. Q., Pires, E. S., and Vivoni, A. M. (2011). Genetic diversity, antimicrobial resistance and toxigenic profiles of Bacillus cereus isolated from food in Brazil over three decades. Int. Food Microbiol. 147, 12-16. doi: 10.1016/j.ijfoodmicro.2011.02.029

Chun, J., Lee, J. H., Jung, Y., Kim, M., Kim, S., Kim, B. K., et al. (2007). EzTaxon: a web-based tool for the identification of prokaryotes based on $16 \mathrm{~S}$ ribosomal RNA gene sequences. Int. J. Syst. Evol. Microbiol. 57, 2259-2261. doi: 10.1099/ijs.0.64915-0 and Zhijie Chen. In addition, we thank the Director, Institute of Tropical Bioscience and Biotechnology, China Academy of Tropical Agricultural Sciences, Haikou, China, for providing facilities for this work, and the Condition of Science and Technology.

Deng, X., Li, Q. F., Hou, X. W., and Wu, C. Y. (2013). Soil microbial functional diversity from different infection grades of banana Fusarium wilt (Fusarium oxysporum f. sp. Cubense). Appl. Mech. Mater. 2301, 2274-2280. doi: 10.4028/www.scientific.net/AMM.295-298.2274

Dhaneesha, M., Benjamin, N. C., Krishnan, K. P., Sinha, R. K., Jayesh, P., Joseph, V., et al. (2017). Streptomyces artemisiae MCCB 248 isolated from Arctic fjord sediments has unique PKS and NRPS biosynthetic genes and produces potential new anticancer natural products. Bio. Tech. 7:32. doi: 10.1007/s13205-017-0610-3

Donio, M., Ronica, S., Viji,V. T., Velmurugan, S., Jenifer, J. A., Michaelbabu, M., et al. (2013). Isolation and characterization of halophilic Bacillus sp. BS3 able to produce pharmacologically important biosurfactants. Asian Pac. J. Trop. Med. 6, 876-883. doi: 10.1016/S1995-7645(13)60156-X

Doumbou, C. L., Hamby Salove, M. K., Crawford, D. L., and Beaulieu, K. (2002). Actinomycetes: promising tools to control plant diseases and to promote plant growth. Phytoprotection 82, 85-102. doi: 10.7202/706219ar

Eccleston, K. L., Brooks, P. R., and Kurtboke, D. I. (2010). Assessment of the role of local strawberry rhizosphere-associated Streptomycetes on the bacterially-induced growth and Botrytis cinerea infection resistance of the fruit. Sustainability 2, 3831-3845. doi: 10.3390/su2123831

El-Tarabily, K. A., and Sivasithamparam, K. (2006). Non-streptomycete actinomycete as biocontrol agents of soil-borne fungal plant pathogens and as plant growth promoters. Soil Biol. Biochem. 38, 1505-1520. doi: 10.1016/j.soilbio.2005.12.017

El-Tarabily, K. A., Soliman, M. H., Nassar, A. H., Al-Hassani, H. A., Sivasithamparam, K., McKenna, F., et al. (2000). Biological control of sclerotinia minor using a chitinolytic bacterium and actinomycetes. Plant Pathol. 49, 573-583. doi: 10.1046/j.1365-3059.2000.00494.x

Espinel-Ingroff, A., and Kerkering, T. M. (1991). Spectrophotometric method of inoculum preparation for the in vitro susceptibility testing of filamentous fungi. J. Clin. Microbiol. 29, 393-394.

Felsenstein, J. (1985). Confidence limits on phylogeny: an appropriate use of the bootstrap. Evolution 39, 783-791. doi: 10.1111/j.1558-5646.1985.tb00420.x

Fitch, W. M. (1971). Toward defining the course of evolution: minimum change for a specific tree topology. Syst. Zool. 20, 406-416. doi: 10.1093/sysbio/20.4.406

Fukunaga, K., Misato, T., Ishii, I., and Asakawa, M. (1955). Blasticidin, a new anti-phytopathogenic fungal substance. Part I. J. Agric. Chem. Soc. 19, 181-188. doi: $10.1271 /$ bbb1924.19.181

Getha, K., and Vikineswary, S. (2002). Antagonistic effects of Streptomyces violaceusniger strain G10 on Fusarium oxysporum $f$. sp. cubense race 4: indirect evidence for the role of antibio-sis in the antagonistic process. J. Ind. Microbiol. Biot. 28, 303-310. doi: 10.1038/sj/jim/7000247

Gonzalez, I., Ayuso-Sacido, A., Anderson, A., and Genilloud, O. (2005). Actinomycetes isolated from lichens: evaluation of their diversityand detection of biosynthetic gene sequences. FEMS Microbio. Ecol. 54, 401-415. doi: 10.1016/j.femsec.2005.05.004

Gordon, R. E., Barnett, D. A., Handerhan, J. E., and Pand, C. H. N. (1974). Nocardia coeliaca, Nocardia autotrophica, and the nocardin strain. Int. J. Syst. Bacteriol. 24, 54-63.

Guan, L. P., Liu, B. Y., Quan, Y. C., Yang, L. Y., Zhen, X. H., and Wang, S. H. (2016) Synthesis and evaluation of phenyliminoindolin-containing phenylacetamide derivatives with the antidepressant and anticonvulsant effects. Medic. Chem. 12, 786-794. doi: 10.2174/1573406412666160201121456

Gupta, V. K., Shivasharanappa, N., Kumar, V., and Kumar, A. (2014). Diagnostic evaluation of serological assays and different gene based PCR for detection of Brucella melitensis in goat. Small Rumin. Res. 117, 94-102. doi: 10.1016/j.smallrumres.2013.11.022

Hastuti, R. D., Lestari, Y., Suwanto, A., and Saraswati, R. (2012). Endophytic Streptomyces spp. as biocontrol agents of rice bacterial leaf blight pathogen (Xanthomonas oryzae pv. oryzae). 19, 155-162. doi: 10.4308/hjb.19.4.155

Himaman, W., Thamchaipenet, A., Pathom-aree, W., and Duangmal, K. (2016). Actinomycetes from eucalyptus and their biological activities for 
controlling eucalyptus leaf and shoot blight. Microbiol. Res. 188-189, 42-52. doi: 10.1016/j.micres.2016.04.011

Hodges, T. W., Slattery, M., and Olson, J. B. (2012). Unique actinomycetes from marine caves and coral reef sediments provide novel PKS and NRPS biosynthetic gene clusters. Mar. Biotechnol. 14, 270-280. doi: 10.1007/s10126-011-9410-7

Hong, K., Gao, A. H., Xie, Q. Y., Gao, H., Zhuang, L., Lin, H. P., et al. (2009). Actino-mycetes for marine drug discovery isolated from man-grove soils and plants in China. Mar Drugs. 7, 24-44. doi: 10.3390/md7010024

Ivanova, V. (1997). New macrolactone of the desertomycin family from Streptomyces spectabilis. Prep. Biochem. Biotech. 27, 19-38. doi: 10.1080/10826 069708001275

Jog, R., Pandya, M., Nareshkumar, G., and Rajkumar, S. (2014). Mechanism of phosphate solubilisation and antifungal activity of Streptomyces sp. Isolated from wheat roots and rhizosphere and their application in improving plant growth. Microbiology 160, 778-788. doi: 10.1099/mic.0.074146-0

Johannes, E., Litaay, M., and Syahribulan. (2016). The bioactivity of hexadecanoic acid compound isolated from hydroid aglaophenia cupressina lamoureoux as antibacterial agent against salmonella typhi. Int. J. Biol. Med. Res. 7, 5469-5472.

Jorjandi, M., Shahidi Bonjar, G. H., Baghizadeh, A., Sharifi Sirchi, G. R., Massumi, H., Baniasadi, F., et al. (2009). Biocontrol of Botrytis allii Munn the causal agent of neck rot, the post harvest disease in onion, by use of a new Iranian Iisolate of Streptomyces. Am. J. Agric. Biol. Sci. 4, 72-81. doi: 10.3844/ajabssp.2009.72.78

Kakinuma, K., Hanson, C. A., and Rinehart, K. L. Jr. (1976). Spectinabilin, a new nitro-containing metabolite isolated from streptomyces spectabilis. Tetrahedron 32, 217-222. doi: 10.1016/0040-4020(76)87004-4

Kelly, K. L. (1958). Centroid notations for the revised ISCC-NBC color name blocks. J. Res. Nat. Bur. Stand. 61, 427-431. doi: 10.6028/jres.061.035

Kim, B. S., Moon, S. S., and Hwang, B. K. (1999). Isolation, identification, and antifungal activity of a macrolide antibiotic, oligomycin A, produced by Streptomyces libani. Can. J. Bot. 77, 850-858. doi: 10.1139/b99-044

Kim, K. R., Kim, T. J., and Suh, J. W. (2008). The gene cluster for spectinomycin biosynthesis and the aminoglycoside-resistance function of spcm in Streptomyces spectabilis. Curr. Microbiol. 57, 371-374. doi: 10.1007/s00284-008-9204-y

Kim, O. S., Cho, Y. J., Lee, K., Yoon, S. H., Kim, M., Na, H., et al. (2012). Introducing EzTaxon-e: a prokaryotic 16S rRNA Gene sequence database with phylotypes that represent uncultured species. Int. J. Syst. Evol. Microbiol. 62, 716-721. doi: 10.1099/ijs.0.038075-0

Kumar, P. S., Duraipandiyan, V., and Ignacimuthu, S. (2014). Isolation, screening and partial purification of antimicrobial antibiotics from soil Streptomyces sp. SCA 7. Kaohsiung J. Med. Sci. 30, 435-446. doi: 10.1016/j.kjms.2014.05.006

Kumar, V., Naik, B., Gusain, O., and Bisht, G. S. (2014). An actinomycete isolatefrom solitary wasp mud nest having strong antibacterial activity and kills the Candida cells due to the shrinkage and the cytosolic loss. Front. Microbiol. 5:446. doi: 10.3389/fmicb.2014.00446

Law, J. W. F., Ser, H. L., Khan, T. M., Chuah, L. H., Pusparajah, P., Chan, K. G., et al. (2017). The Potential of streptomyces as biocontrol agents against the rice blast fungus, Magnaporthe oryzae (Pyricularia oryzae). Front. Microbiol. 8:3. doi: 10.3389/fmicb.2017.00003

Lu, D. D., Ma, Z., Xu, X. H., and Yu,. X. P. (2016). Isolation and identification of biocontrol agent Streptomyces rimosus M527 against Fusarium oxysporum $\mathrm{f}$. sp. Cucumerinum. J. Basic. Microbiol. 56, 929-933. doi: 10.1002/jobm.201500666

Lyu, A., Liu, H., Che, H., Yang, L., Zhang, J., Wu, M., et al. (2017). Reveromycins A and B from Streptomyces sp. 3-10: antifungal activity against plant pathogenic fungi in vitro and in a strawberry food model system. Front. Microbiol. 8:550. doi: $10.3389 /$ fmicb. 2017.00550

Mahadevan, B., and Crawford, D. L. (1997). Properties of the chitinase of the antifungal biocontrol agent Streptomyces lydicus WYEC108. Enzyme Microb. Technol. 20, 489-493. doi: 10.1016/S0141-0229(96)00175-5

Marques, A. P. G. C., Pires, C., Moreira, H., Rangel, A. O. S. S., and Castro, P. M. L. (2010). Assessment of the plant growth promotion abilities of six bacterial isolates using zea mays as indicator plant. Soil Biol. Biochem. 42, 1229-1235. doi: 10.1016/j.soilbio.2010.04.014

Mingma, R., Pathom-aree, W., Trakulnaleamsai, S., Thamchaipenet, A., and Duangmal, K. (2014). Isolation of rhizospheric and roots endophytic actinomycetes from Leguminosae plant and their activities to inhibit soybean pathogen Xanthomonas campestris pv. glycine. World J. Microbiol. Biotechnol. 30, 271-280. doi: 10.1007/s11274-013-1451-9
Nguyen, X. H., Naing, K. W., Lee, Y. S., Kim, Y. H., Moon, J. H., and Kim, K. Y. (2015). Antagonism of antifungal metabolites from Streptomyces griseus H7602 against Phytophthora capsici. J. Basic. Microbiol. 55, 45-53. doi: 10.1002/jobm.201300820

Nimaichand, S., Devi, A. M., Tamreihao, K., Ningthoujam, D. S., and Li, W. J. (2015). Actinobacterial diversity in limestonedeposit sites in Hundung, Manipur (India) and their antimicrobial activities. Front. Microbiol. 6:413. doi: 10.3389/fmicb.2015.00413

Noda, Y., Masumizu, T., and Mori, A. (2016). The anticonvulsant zonisamide inhibits hydroxyl radical generated from methylguanidine. Acta Med. Okayama. 70, 371-375. doi: 10.18926/AMO/54595

Ntalli, N., Oplos, C., Michailidis, M., Thanasenaris, A., Kontea, D., Caboni, P., et al. (2016). Strong synergistic activity and egg hatch inhibition by (E,E)-2,4decadienal and (E)-2-decenal in Meloidogyne species. J. Pest. Sci. 89, 565-579. doi: 10.1007/s10340-015-0711-x

Passari, A. K., Mishra, V. K., Saikia, R., Gupta, V. K., and Singh, B. P. (2015). Isolation, abundance and phylogenetic affiliation of endophytic actinomycetes associated with medicinal plants and screening for their in vitro antimicrobial biosynthetic potential. Front. Microbiol. 6:273. doi: 10.3389/fmicb.2015.00273

Patel, J. B., Tenover, F. C., Turnidge, J. D., and Jorgensen, J. H. (2011). Susceptibility test methods: dilution and disk diffusion methods. Manual. Clin. Microbiol. 68, 1122-1143. doi: 10.1128/9781555816728.ch68

Pitcher, D. G., Saunders, N. A., and Owen, R. J. (1989). Rapid extraction of bacterial genomic DNA with guanidium thiocyanate. Lett. Appl. Microbiol. 8, 151-156. doi: 10.1111/j.1472-765X.1989.tb00262.x

Prapagdee, B., Kuekulvong, C., and Mongkolsuk, S. (2008). Antifungal potential of extracellular metabolites produced by Streptomyces hygroscopicus against phytopathogenic fungi. Int. J. Biol. Sci. 4, 330-337. doi: 10.7150/ijbs.4.330

Qin, S., Xing, K., Jiang, J. H., Xu, L. H., and Li, W. J. (2011). Biodiversity, bioactive natural products and biotechnological potential of plant-associated endophytic actinobacteria. Appl. Microbiol. Biotechnol. 89, 457-473. doi: 10.1007/s00253-010-2923-6

Rahman, M. S., and Anwar, M. N. (2006). Fungitoxic and cytotoxic activity of a novel compound 1,2-benzenedicarboxylic acid, diisooctyl ester of Plumbago zeylanica linn. Asian J. Microbiol. Biot. Environ. Sci. 8, 461-464.

Rungin, S., Indananda, C., Suttiviriya, P., Kruasuwan, W., Jaemsaeng, R., and Thamchaipenet, A. (2012). Plant growth enhancing effects by a siderophoreproducing endophytic streptomycete isolated from a Thai jasmine rice plant (Oryza sativa L. cv. KDML105). Antonie van Leeuwenhoek. 102, 463-472. doi: 10.1007/s10482-012-9778-z

Sadeghian, M., Bonjar, G. H. S., and Sirchi, G. R. S. (2016). Post harvest biological control of apple bitter rot by soil-borne actinomycetes and molecular identification of the active antagonist. Postharvest Biol. Tec. 112, 46-54. doi: $10.1016 /$ j.postharvbio.2015.09.035

Saitou, N., and Nei, M. (1987). The neighbor-joining method: a new method for reconstructing phylogenetic trees. Mol. Biol. Evol. 4, 406-425.

Saremi, H., and Okhovvat, S. M. (2006). Mycotoxin producing Fusarium species associated with plant disease on potato, wheat, corn and animal diseases in northwest Iran. Commun. Agric. Appl. Biol. Sci. 71, 1175-1185.

Sasaki, T., Igarashi, Y., Ogawa, M., and Furumai, T. (2002). Identification of 6-prenylindole as an antifungal metabolite of Streptomyces sp. TP-A0595 and synthesis and bioactivity of 6-substituted indoles. J. Antibiot. 55, 1009-1012.

Savary, S., Teng, P. S., Willocquet, L., and Nutter Jr. F. W. (2006). Quantification and modeling of crop losses: a review of purposes. Annu. Rev. Phytopathol. 44, 89-112. doi: 10.1146/annurev.phyto.44.070505.143342

Savic, M., Bratic, I., and Vasiljevic, B. (2007). Streptomyces durmitorensis sp. nov., a produer of an FK506-like immunosuppressant. Int. J. Syst. Evol. Microbiol. 57, 2119-2124. doi: 10.1099/ijs.0.64913-0

Seipke, R. F., Barke, J., Brearley, C., Hill, L., Yu, D. W., Goss, R. J. M., et al. (2011). A single Streptomyces symbiont makes multiple antifungals to support the fungus farming ant Acromyrmex octospinosus. PLoS ONE 6:e22028. doi: 10.1371/journal.pone.0022028

Selvakumar, J., Chandrasekaran, S., and Vaithilingam, M. (2015). Bio prospecting of marine-derived Streptomyces spectabilis VITJS10 and exploring its cytotoxicity against human liver cancer cell lines. Pharmacognosy Magazine. 11, 469-473. doi: 10.4103/0973-1296.168974

Ser, H. L., Ab-mutalib, N., Yin, W. F., Chan, K. G., Goh, B., and Lee, L. H. (2015b). Evaluation of antioxidative and cytotoxic activities of Streptomyces pluripotens 
MUSC137 isolated from mangrove soil in Malaysia. Front. Microbiol. 6:1398. doi: $10.3389 /$ fmicb. 2015.01398

Ser, H. L., Palanisamy, U. D., Yin, W. F., AbdMalek, S. N., Chan, K. G., Goh, B. H., et al. (2015a). Presence of antioxidative agent, pyrrolo[1,2-a]pyrazine-1,4dione, hexahydro- in newly isolated Streptomyces mangrovisoli sp. nov. Front. Microbiol. 6:854. doi: 10.3389/fmicb.2015.00854

Ser, H. L., Tan, L. T. H., Palanisamy, U. D., Abd Malek, S. N., Yin, W. F., Chan,. K. G., et al. (2016). Streptomyces antioxidans sp. nov., a novel mangrove soil actinobacterium with antioxidative and neuroprotective potentials. Front. Microbiol. 7:899. doi: 10.3389/fmicb.2016.00899

Sharma, A., Rajendran, S., Srivastava, A., Sharma, S., and Kundu, B. (2017). Antifungal activities of selected essential oils against Fusarium oxysporum $f$. sp. lycopersici 1322, with emphasis on Syzygium aromaticum essential oil. J. Biosci. Bioeng. 123, 308-313. doi: 10.1016/j.jbiosc.2016.09.011

Sharma, P., Kalita, M. C., and Thakur, D. (2016). Broad spectrum antimicrobial activity of forest-derived soil actinomycete, Nocardia sp. PB-52. Front. Microbiol. 7:347. doi: 10.3389/fmicb.2016.00347

Shirling, E. B., and Gottlieb, D. (1966). Methods for characterization of Streptomyces species. Int. J. Syst. Evol. Microbiol. 16, 313-340. doi: 10.1099/00207713-16-3-313

Shivlata, L., and Satyanarayana, T. (2015). Thermophilic and alkaliphilic Actinobacteria: biology and potential applications. Front. Microbiol. 6:1014. doi: $10.3389 /$ fmicb. 2015.01014

Smith, R., Peterson, W., and Mccoy, E. (1954). Oligomycin, a new antifungal antibiotic. Antibiot. Chemother. 4, 962-970.

Spasova, D., Vesselinova, N., and Gesheva, R. (1997). Comparative investigation of a streptovaricin-producing strain of Streptomyces spectabilis and its selectant. Folia Microbiol. 42, 35-38. doi: 10.1007/BF02898643

Srivastava, V., and Dubey, A. K. (2016). Anti-biofilm activity of the metabolites of Streptomyces chrestomyceticus strain ADP4 against Candida albicans. J. Biosci. Bioeng. 122, 434-440. doi: 10.1016/j.jbiosc.2016.03.013

Sun, W., Zhang, F., He, L., Karthik, L., and Li, Z. (2015). Actinomycetes fromthe South China Sea sponges: isolation, diversity, and potential for aromaticpolyketides discovery. Front. Microbiol. 6:1048. doi: $10.3389 /$ fmicb. 2015.01048

Supaphon, P., Phongpaichit, S., Rukachaisirikul, V., and Sakayaroj, J. (2013). Antimicrobial potential of endophytic fungi derived from three seagrass species: Cymodocea serrulata, Halophila ovalis and Thalassia hemprichii. PLoS ONE 8:e72520. doi: 10.1371/journal.pone.0072520

Supriady, H., Kamarudin, M. N. A., Chan, C. K., Goh, B. H., and Kadir, H. A. (2015). SMEAF attenuates the production of pro-inflammatory mediatorsthrough the inactivation of Akt-dependent NF- $\mathrm{B}, \mathrm{p} 38$ and ERK1/2 pathwaysin LPS-stimulated BV-2 microglial cells. J. Funct. Foods. 17, 434-448. doi: 10.1016/j.jff.2015.05.042

Swain, M. R., and Ray, R. C. (2009). Biocontrol and other beneficial activities of Bacillus subtilis isolated from cowdung microflora. Microbiol. Res. 164, 121-130. doi: 10.1016/j.micres.2006.10.009

Tamura, K., Dudley, J., Nei, M., and Kumar, S. (2007). MEGA4, molecular evolutionary genetics analysis (MEGA) software version 4.0. Mol. Biol. Evol. 24, 1596-1599. doi: 10.1093/molbev/msm092

Tan, L. T. H., Chan, K. G., Lee, L. H., and Goh, B. H. (2016). Streptomyces bacteria as potential probiotics in aquaculture. Front. Microbiol. 7:79. doi: 10.3389/fmicb.2016.00079

Tan, L., Ser, H., Yin, W., Chan, K., Lee, L., and Goh, B. (2015). Investigation of antioxidative and anticancer potentials of Streptomyces sp. MUM256 isolated from Malaysia Mangrove Soil. Front. Microbiol. 6:1316. doi: $10.3389 /$ fmicb. 2015.01316

Tapadar, S. A., and Jha, D. K. (2013). Disease Management in Staple Crops: A Bacteriological Approach. Bacteria in Agrobiology: Disease Management. Berlin; Heidelberg: Springer.

Thompson, J. D., Gibson, T. J., Plewniak, F., Jeanmougin, F., and Higgins, D. G. (1997). The Clustal X windows interface: flexiblestrategies for multiple sequence alignment aided by qualityanalysis tools. Nucleic Acids Res. 25, 4876-4882. doi: 10.1093/nar/25.24.4876

Tzortzakis, N. G., and Economakis, C. D. (2007). Antifungal activity of lemongrass (Cympopogon citratus L.) essential oil against key postharvest pathogens. Innov. Food Sci. Emerging. Technol. 8, 253-258. doi: 10.1016/j.ifset.2007.01.002

Ueno, M., Quyet, N. T., Shinzato, N., and Matsui, T. (2016). Antifungal activity of collected in subtropical region, Okinawa, against
Magnaporthe oryzae. Trop. Agricult. Dev. 60, 48-52. doi: 10.11248/ jsta.60.48

Uphoff, N., Anas, I., Rupela, O. P., Thakur, A. K., and Thyagarajan, T. M. (2009). Learning about positive plant-microbial interactions from the system of rice intensification (SRI). Aspect. Appl. Biol. 98, 29-54.

Wang, B. B., Shen, Z. Z., Zhang, F. G., Waseem, R., Yuan, J., Huang, R., et al. (2016). Bacillus amyloliquefaciens strain W19 can promote growth and yield and suppress Fusarium wilt in banana under greenhouse and field conditions. Pedosphere 26, 733-744. doi: 10.1016/S1002-0160(15)60083-2

Wang, C. L., Wang, Z. F., Qiao, X., Li, Z. J., Li, F. J., Chen, M. H., et al. (2013). Antifungal activity of volatile organic compounds from Streptomyces alboflavus TD-1. Fems Microbiol. Lett. 341, 45-51. doi: 10.1111/1574-6968.12088

Wang, J. J., Zhao, Y., and Ruan, Y. Z. (2015). Effects of bio-organic fertilizers produced by four Bacillus amyloliquefaciens strains on banana Fusarium wilt Disease. Compost Sci. Util. 23, 185-198. doi: 10.1080/1065657X.2015.1020398

Wang, L. Y., Xing, M. Y., Di, R., and Luo, Y. P. (2015). Isolation, identification and antifungal activities of Streptomyces aureoverticillatus HN6. J. Plant Pathol. Microb. 6:281. doi: 10.4172/2157-7471.1000281

Wang, X. J., Zhang, J., Wang, J. D., Qian, P. T., Liu, C. X., and Xiang, W. S. (2013). Novel cyclopentenone derivatives produced by a rare actinobacterial strain Actinoalloteichus nanshanensis sp. nov. NEAU 119. Nat. Prod. Res. 27, 1863-1869. doi: 10.1080/14786419.2013.771349

Wang, X. N., Radwan, M. M., Taráwneh, A. H., Gao, J. T., Wedge, D. E., Rosa, L. H. et al. (2013). Antifungal activity against plant pathogens of metabolites from the endophytic fungus cladosporium cladosporioides. J. Agric. Food Chem. 61, 4551-4555. doi: 10.1021/jf400212y

Wedge, D. E., Curry, K. J., Boudreaux, J. E., Pace, P. F., and Smith, B. J. (2003). A microtiter assay demonstrates sensitivity and resistance profiles for Botrytis cinerea isolates from Louisiana strawberry farms. Adv. Strawberry Res. 20, 27-33.

Wedge, D. E., and Kuhajek, J. M. (1998). A microbioassay for fungicide discovery. SAAS Bull. Biochem. Biotech. 11, 1-7.

Whiton, R. S., Lau, P., Morgan, S. L., Gilbart, J., and Fox, A. (1985). Modifications in the alditol acetate method for analysis of muramic acid and other neutral and amino sugars by capillary gas chromatography-mass spectrometry with selected ion monitoring. J. Chromato. A. 347, 109-120. doi: 10.1016/S0021-9673(01)95474-3

Williams, P. G. (2009). Panning for chemical gold: marine bacteria as a sourceof new therapeutics. Trends Biotech. 27, 45-52. doi: 10.1016/j.tibtech.2008.10.005

Williams, S. T., Goodfellow, M., Alderson, G., Wellington, E. M. H., Sneath, P. H. A., and Sackin, M. J. (1983). Numerical classification of Streptomyces and related genera. J. Gen. Microbiol. 129, 1743-1813. doi: 10.1099/00221287-129-6-1743

Yang, P. W., Li, M. G., Zhao, J. Y., Zhu, M. Z., Shang, H., Li, J. R., et al. (2010). Oligomycins A and C, major secondary metabolites isolated from the newly isolated strain Streptomyces diastaticus. Folia Microbiol. 55, 10-16. doi: 10.1007/s12223-010-0002-0

Yogeswari, S., Ramalakshmi, S., Neelavathy, R., and Muthumary, J. (2012). Identification and comparative studies of different volatile fractions from Monochaetia kansensis by GCMS. Global J. Pharmacol. 6, 65-71.

Yuan, W. M., and Crawford, D. L. (1995). Characterization of Streptomyces lydicus WYEC108 as a potential biocontrol agent against fungal root and seed rots. Appl. Environ. Microbiol. 61, 3119-3128.

Zhu, Y. J., Zhou, H. T., Hu, Y. H., Tang, J. Y., Su, M. X., Guo, Y. J., et al. (2011). Antityrosinase and antimicrobial activities of 2-phenylethanol, 2-phenylacetaldehyde and 2-phenylacetic acid. Food Chem. 124, 298-302. doi: 10.1016/j.foodchem.2010.06.036

Conflict of Interest Statement: The authors declare that the research was conducted in the absence of any commercial or financial relationships that could be construed as a potential conflict of interest.

Copyright (C) 2018 Chen, Zhou, Qi, Gao, Xie and Luo. This is an open-access article distributed under the terms of the Creative Commons Attribution License (CC BY). The use, distribution or reproduction in other forums is permitted, provided the original author(s) or licensor are credited and that the original publication in this journal is cited, in accordance with accepted academic practice. No use, distribution or reproduction is permitted which does not comply with these terms. 